\title{
Imagenología aplicada a las momias de Tlayacapan, Morelos, México
}

\section{Imaging study in mummies of Tlayacapan, Morelos, Mexico}

\author{
Judith L. Ruiz-González1 \\ Universidad Nacional Autónoma de México \\ (iD) https://orcid.org/0000-0002-0173-5960
}

\section{Carlos Serrano-Sánchez ${ }^{2}$ \\ Universidad Nacional Autónoma de México \\ (iD https://orcid.org/0000-0001-6194-4281}

\begin{abstract}
Resumen: Las momias de Tlayacapan, Morelos, de inicios del siglo XIX, representan un sector de la élite del poblado y quizá el más vulnerable por tratarse en su mayoría de infantes. A través del análisis imagenológico realizado en ellas, se pudo concluir que el estatus social de las momias de Tlayacapan no garantizó la sobrevivencia a edades mayores de los individuos momificados; aun para la gente acomodada del lugar fue difícil contrarrestar la mortalidad a ciertas edades de la vida, sobre todo en un periodo crítico en la ontogenia humana. En el siglo XIX se hace referencia constante a la muerte infantil debida a enfermedades mortales que inciden durante los primeros años de vida postnatal. Este trabajo contribuye al conocimiento sobre las condiciones y el estilo de vida que imperaban hacia finales del periodo novohispano, en uno de los poblados aledaños a la Ciudad de México.

Palabras clave: momificación; México; siglo XIX; estrés fisiológico; condiciones de vida.
\end{abstract}

Recibido: 31/01/2019 | Aceptado: 24/10/2019 | Disponible en línea: 15/12/2019

Cómo citar este artículo: Ruiz-González, J. L, Serrano-Sánchez, C. (2020). Imagenología aplicada a las momias de Tlayacapan, Morelos, México. Jangwa Pana, 19(1), 45 - 84. Doi:

https://doi.org/10.21676/16574923.3357

Abstract: The mummies of Tlayacapan, Morelos, from the beginning of the 19th century, represent a sector of the elite of the town and perhaps the most vulnerable, since they are mostly infants. Through the imaging analysis carried out in them, the social status of the mothers of Tlayacapan could be concluded without guaranteeing survival at the older ages of mummified individuals; even for the noble and well-off people of the place it was difficult to counteract morbidity at certain ages of life, especially in a critical period in human ontogeny. Still in the nineteenth century constant references were made to the infant death, due to deadly diseases that affect during the first years of postnatal life. This work contributes to the knowledge about the conditions and life style that prevailed towards the end of the New Spain period, in one of the towns around Mexico City.

Key words: mummification, Mexico, 19th century, physiological stress, living conditions

\footnotetext{
${ }^{1}$ Correo electrónico: sundury_liz@yahoo.com.mx.

${ }^{2}$ Correo electrónico: cserrano@unam.mx.
} 


\section{Introducción}

Los cuerpos momificados son un tema de reflexión para la antropología física en tanto constituyen la evidencia directa de grupos que habitaron en el pasado. A través de diversas investigaciones interdisciplinarias sobre estos restos, se pueden conocer aspectos culturales, biológicos y de las formas de vida de la época a la que corresponden.

Las momias de Tlayacapan, como muchos de los hallazgos accidentales de este género que se han dado en la república mexicana, son producto de un proceso natural de desecación debido a las condiciones que se crearon en el lugar de enterramiento. Su descubrimiento se remonta a mayo de 1982, cuando los trabajadores que realizaban labores de remodelación del piso de la iglesia de San Juan Bautista en Tlayacapan, Morelos, inesperadamente encontraron cuerpos momificados dentro de esta construcción colonial que data del siglo XVI. El Instituto Nacional de Antropología e Historia (INAH) de Morelos intervino en su exploración, la cual estuvo a cargo del arqueólogo Arturo Oliveros (1990).

Para llevar a cabo la exploración arqueológica, la excavación se remitió al área del presbiterio, donde se localizaron tres niveles de enterramiento. En el último y más superficial se preservaron totalmente los cadáveres, que en su mayoría corresponden a niños, además de unos pocos adultos. Entre las particularidades de estos personajes destaca la manera en que su cuerpo fue tratado para su subsecuente sepultura, bajo pautas cristianas que son imprescindibles dentro de la sociedad colonial. Tal es el caso de la orientación, el tipo de vestimenta y el uso de ataúdes de madera (Oliveros, 1990), rasgos que en la actualidad perviven dentro de las costumbres funerarias del poblado.

De los 39 entierros humanos excavados, se seleccionaron nueve momias para ser exhibidas en un museo local que hoy en día las alberga en el refectorio de la edificación conventual, junto con arte sacro agustino de la época. Estas nueve momias son el tema de la presente investigación.

Las momias de Tlayacapan, Morelos, retratan un fragmento del sistema de pensamiento de inicios del siglo XIX, esto es, el tratamiento del cuerpo y las costumbres funerarias católicas instauradas por las concepciones socioculturales en una sociedad colonial, que plasmó el estilo de vida en la jerarquización de los sectores sociales.

El tipo de enterramiento que se les brindó a estos individuos denota el estatus social al que pertenecieron. Probablemente estuvieron emparentados entre ellos, pues se encontraron sepultados dentro del espacio funerario más cercano al altar de la iglesia en que fueron exhumados y, de acuerdo a la costumbre de la época, era común realizar sepulcros de un mismo linaje familiar en el espacio que habían adquirido para ello (Rodríguez-Álvarez, 2001). Es posible, asimismo, que su muerte ocurriera en un lapso corto, pues no es evidente un tratamiento mortuorio que difiera en los entierros localizados en el estrato más reciente de los sepulcros. También son apreciables el cuidado y el tiempo dedicados al difunto para su sepultura.

En varios estados de la república mexicana (Zacatecas, Morelos, Hidalgo, Puebla, Ciudad de México y Yucatán) se han encontrado fortuitamente restos momificados en el interior de conventos o templos coloniales construidos en el siglo XVI. Las momias coloniales, al igual que las procedentes de la época prehispánica, son consideradas patrimonio 
cultural, histórico y arqueológico; por ello son un gran campo de estudio para los especialistas que dirigen su mirada hacia el pasado ${ }^{3}$.

Los primeros estudios en cuerpos momificados surgieron en el siglo XVIII, con el inicio del examen anatómico a través de autopsias en momias egipcias. De ahí hasta la actualidad se han encaminado hacia la adopción de un enfoque multidisciplinar, valiéndose de diversas técnicas y métodos de otras áreas de investigación que han aportado nuevos datos a la historia antigua (Rae-Simms, 2012).

Existe una diversidad de métodos empleados en el análisis de restos momificados, los cuales se aplican dependiendo del tipo de momificación y la disponibilidad de recursos para realizarlos. En general, los métodos de análisis de momias se dividen en tres tipos: morfológicos, físicos y bioquímicos. A su vez, los primeros se dividen en macro y microscópicos, con la finalidad de observar la morfología del cuerpo; los del segundo tipo se apoyan en técnicas no destructivas para acceder a las cavidades y estructuras del organismo (Aufderheide, 2003; Bautista-Martínez, Gómez-Valdés y Monterroso-Rivas, 2012), y los últimos se emplean cuando es preciso tomar muestras de tejido, cabello, hueso, etc., para análisis en laboratorio.

En las momias procedentes de la república mexicana se han aplicado algunos de estos exámenes (Batres, 1889; Bautista-Martínez, Gómez-Valdez y Ortega-Palma, 2010; Leboreiro-Reyna, 2004; 2005; Lerma-Gómez, 2008; López-Martínez, HernándezHernández, Millán, Manzano y Méndez Tovar, 2007; Mansilla-Lory, 2002; MárquezMorfín y González-Crespo, 1985; Medina-Monzón, 1993; Mejía-Pérez, Chávez-Balderas y Chávez-Sánchez, 2009; Menéndez-Taboada, 2006; Pijoan-Aguade y LizárragaCruchaga, 2004; Rojo-Pérez, 1998; Sánchez-Crispín, 2009). Sin embargo, la mayoría de los estudios se enfocan en la identificación de bacterias y hongos para su manejo apropiado y su conservación y resguardo, que muchas veces llega a ser inadecuado, pues las momias se encuentran depositadas en bodegas como cualquier otro material arqueológico (Bautista-Martínez et al., 2010; Lerma-Gómez 2008; López et al., 2007; Mejía-Pérez et al., 2009; Rojo-Pérez, 1998; Ruiz-González, Bazán-Mora, BarreraMoreno y López-Martínez, 2016; Sánchez-Crispín, 2009).

La radiología es en la actualidad el método más empleado para el estudio tanto de restos óseos como de restos momificados debido a la posibilidad de traslado de equipos portátiles, por su accesibilidad económica y porque permite observar la estructura interna del cuerpo sin destruirlo o deteriorarlo. A través de este método es posible conocer algunas enfermedades que afectaron en el pasado; el estado general de preservación, especialmente de los órganos internos y la estructura ósea; la edad del individuo en el momento de la muerte, y el sexo, entre otros.

En México, el estudio de las momias en el marco de las ciencias antropológicas ha sido muy restringido. Las investigaciones se centran principalmente en la descripción del ajuar funerario, así como en la manera en que se llevó a cabo el proceso de momificación en un contexto particular; en algunos casos, también se ha tenido la preocupación de la preservación del material y la exhibición a nivel regional o nacional. Las momias de

\footnotetext{
${ }^{3}$ El patrimonio cultural se puede definir desde distintos ángulos. Para el mercado, es un conjunto de bienes cuyo valor se incrementa debido a su escasez y antigüedad; para las instituciones gubernamentales, es un conjunto de bienes que se debe legislar, regular y administrar, y para los especialistas es un campo de estudio (Insaurralde-Caballero, 2012, p. 30).
} 
Tlayacapan, en particular, solo cuentan con un estudio previo que describe los hallazgos de carácter arqueológico y funerario, realizado por el arqueólogo Arturo Oliveros (1990).

El objetivo de esta investigación es conocer las condiciones de salud de los individuos a quienes corresponden varios restos momificados que fueron localizados en el interior de la iglesia de San Juan Bautista, en el poblado de Tlayacapan, empleando técnicas imagenológicas como los rayos X. La aplicación de este método permite identificar la presencia de indicadores de respuesta al estrés, los cuales proporcionan un medio para la evaluación del estado de salud y de la nutrición (Goodman y Martin, 2002).

\section{Tlayacapan: situación geográfica, poblamiento e historia}

Tlayacapan es uno de los 33 municipios que integran el estado de Morelos y se ubica en la parte norte del territorio morelense (figura 1). En general, Morelos cuenta con un clima subtropical debido al declive constante del subsuelo de norte a sur, aunque en la región norte, que corresponde a los altos de Morelos, se presenta un clima cálido y húmedo con temperaturas templadas e inviernos notables.

Figura 1. Ubicación del poblado de Tlayacapan, en el estado de Morelos, México

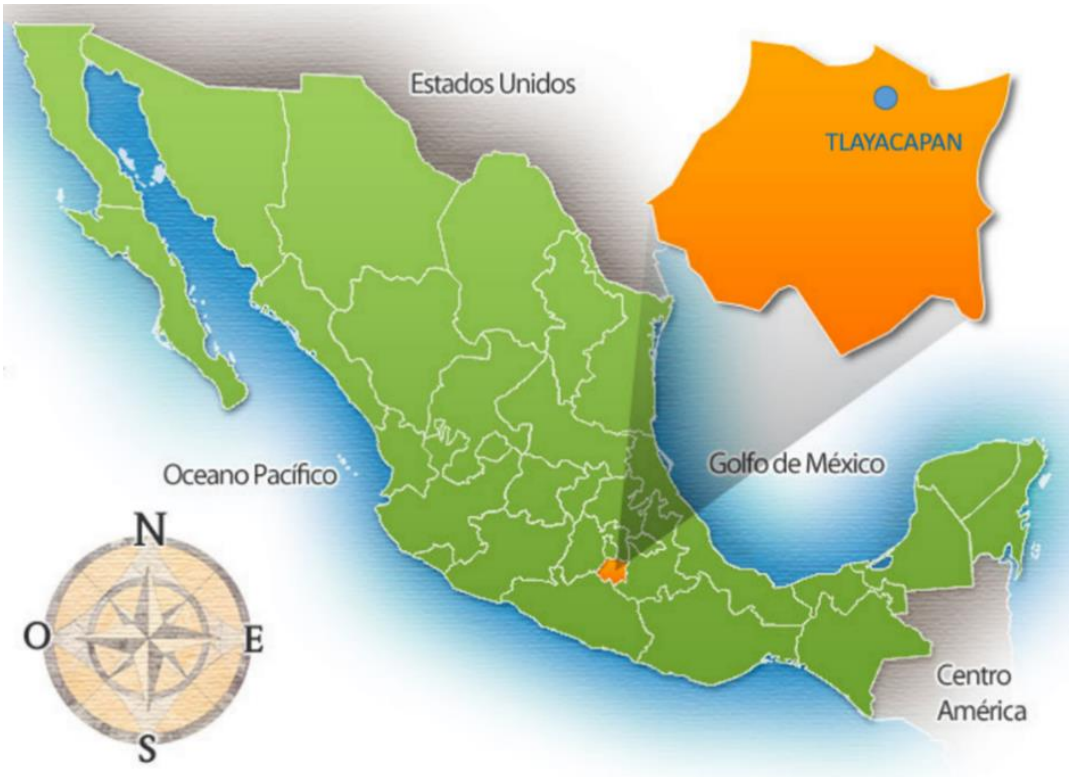

Fuente: https://mr.travelbymexico.com/704-estado-de-morelos.

El estado de Morelos ha tenido una larga ocupación que se remonta a los primeros asentamientos humanos de cazadores y recolectores, entre los años 7000 y 2500 a. C. Durante el Preclásico medio (1000-500 a. C.) los olmecas habitaron parte de esta región. Posteriormente, hay evidencia de la cultura tolteca hacia el año 603 d. C., y de la cultura mexica hacia el Posclásico tardío (Ávila-Sánchez, 2002).

En lo que refiere al contacto con el Nuevo Mundo, Bernal Díaz del Castillo relata en su obra el paso de este a oeste de Hernán Cortés y su ejército por los distintos poblados de la región de Morelos. Ya entrada la conquista, por los servicios prestados a la Corona española, el rey Carlos V gratificó a Hernán Cortés en 1529 con el nombramiento de Marqués del Valle de Oaxaca, que abarcó 22 villas y lugares en las tierras conquistadas, además de 23000 vasallos. Este marquesado comprendió la Vera Cruz, Tuxtla y los valles de Toluca, Oaxaca y Tehuantepec, así como las tierras del actual estado de Morelos 
(López-González, 1994). En el transcurso de la Colonia, Morelos pasó a formar parte de la provincia de México en 1646, cuando se denominó Audiencia de México a la provincia de México y se realizó la división territorial (Ávila-Sánchez, 2002).

La orden de los agustinos, que fue designada para evangelizar este territorio, estableció una red de conventos para formar una línea de comunicación entre la Ciudad de México y las otras misiones. La magnificencia arquitectónica de los conventos, sin duda, tenía un propósito, y este era impactar a los neoconversos para reforzar el cristianismo por medio de los sentidos (Rubial-García, 1989) (figura 2).

Figura 2. Fachada del exconvento de Tlayacapan, Morelos

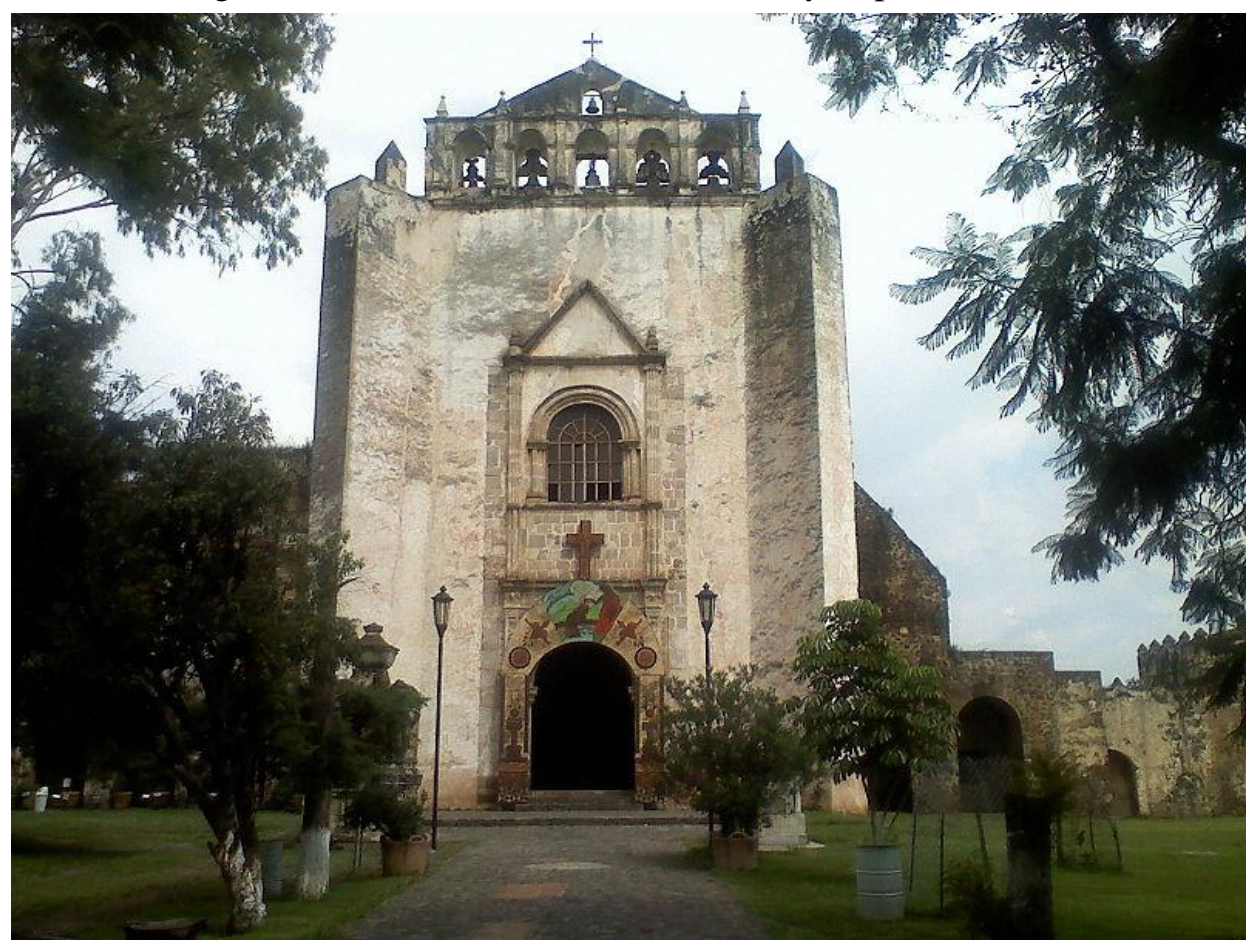

Fuente: https://es.wikipedia.org/wiki/Tlayacapan.

A lo largo de la historia de las sociedades, diversos cambios en las concepciones religiosas e ideológicas han originado actitudes respecto a la muerte, las cuales han provocado un impacto social. Cada época histórica ha hecho frente a este fenómeno de manera diferente.

Si bien la muerte como hecho biológico afecta a todos por igual: ricos, pobres, plebeyos, religiosos, laicos, etc., morir también es un hecho social y cultural. Al fin de toda vida las diferencias se mantienen; así, en tanto que algunos gozan de un tratamiento privilegiado, los pobres se remiten a cumplir los pasos básicos para el ritual acostumbrado, bajo los preceptos del cristianismo. Asimismo, durante la época novohispana, la muerte entre los nobles configuraba el modelo que se debía seguir entre los estratos más bajos del escalafón social. Sin embargo, en ambos casos cabía la posibilidad de una variedad de las honras fúnebres hacia el difunto.

Las circunstancias que involucran la muerte son varias, y entre ellas cabe considerar las condiciones de vida favorables, que hacen más llevaderas las vicisitudes de la vida. Tales privilegios se obtenían en virtud de la capacidad económica, la cual brindaba mayor seguridad de cara a la salvación; por ejemplo, mejores lugares de entierro, mayores 
sufragios e interseciones, así como mayores probabilidades de defensa ante enfermedades y epidemias (Sánchez del Olmo, 2009; Soto-Cortés, 2010).

En torno a la resurrección, se consideraba que esta era posible a través del depósito de los cuerpos cerca de un espacio sagrado o alrededor de él. Tal es el caso de templos e iglesias, atrios, capillas y, posteriormente, cementerios. Asimismo, se requería el acompañamiento de un rito católico. El espacio designado para el sepulcro representaba la Ciudad de Dios, y en él se proyectaban el estatus y el poder social de cada persona, de manera que solo unos cuantos podían acceder a los espacios próximos al altar. De este modo, el espacio fue jerarquizado y reservado a las élites, las cuales se concebían diferentes al resto de la población, por lo que su muerte también debía ser distinta (Sánchez del Olmo, 2009).

\section{La momificación en México}

La momificación implica la transformación una vez que el cuerpo o tejido ha detenido la fase de descomposición después de la muerte (Aufderheide, 2003). En este proceso interactúan factores bioquímicos, geofísicos y climatológicos para crear un microambiente específico con ciertas condiciones de aire, humedad y calor que imposibilitan la proliferación de flora y fauna cadavérica, responsables de causar la descomposición. De esta manera se preservan varios de los componentes orgánicos de los cadáveres, debido a la naturaleza o bien a la acción del hombre (Medina-Monzón, 1993; Pijoan-Aguade y Lizárraga-Cruchaga, 2004).

Son varias las causas que afectan la transformación del cuerpo; por ello se cuenta con una clasificación que da cuenta de las circunstancias que han favorecido dicha preservación. Básicamente, los tipos de momificación son tres, y cada uno es producto de múltiples mecanismos que inciden sobre los cuerpos (Aufderheide, 2003; Cockburn, Cockburn y Reyman, 1998):

1) La momificación natural o espontánea se debe a factores del medio ambiente físico como la sequedad, el frío, el calor, la congelación, la anaerobiosis, entre otros. En general, las condiciones para este tipo de momificación son una matriz de suelo seco o helado, temperaturas constantes todo el año, un ambiente anaeróbico y la intervención de sales minerales, agua mineralizada, ácido tánico y sustancias muy absorbentes.

2) La momificación artificial o antrópica es el resultado de la intervención deliberada del ser humano para la preservación de sus cadáveres por medio de una gran variedad de técnicas como la evisceración; el embalsamamiento con el uso de resinas, aceites, hierbas y otros materiales orgánicos y químicos; la desecación inducida, debida al fuego y/o humo; la plastinación, y la criogenización.

3) La momificación natural inducida es el efecto intermedio entre las dos anteriores. Ocurre cuando el hombre adquiere conocimiento de que el ambiente físico o situaciones propicias son ideales para la momificación natural sin el tratamiento por manos humanas, y lo aplica a sus muertos con ese propósito. Por ejemplo, coloca el cuerpo en áreas favorables para su conservación.

En lo que respecta a México, se han descubierto restos momificados o parcialmente momificados, tanto de humanos como de animales, en varios estados de la república mexicana (figura 3). Hasta el momento se puede decir que son producto de un proceso natural de desecación provocado por diversos factores que interactúan entre sí: temperatura, humedad, clima o composición del suelo donde los cuerpos fueron 
depositados, además del tipo de ajuar funerario y del mausoleo. Todos ellos suspenden la descomposición del cadáver durante un periodo prolongado hasta su descubrimiento, aunque luego, al despojar a este de su depósito de origen, se renueva el proceso natural de descomposición.

Figura 3. Mapa de la momificación en México por épocas

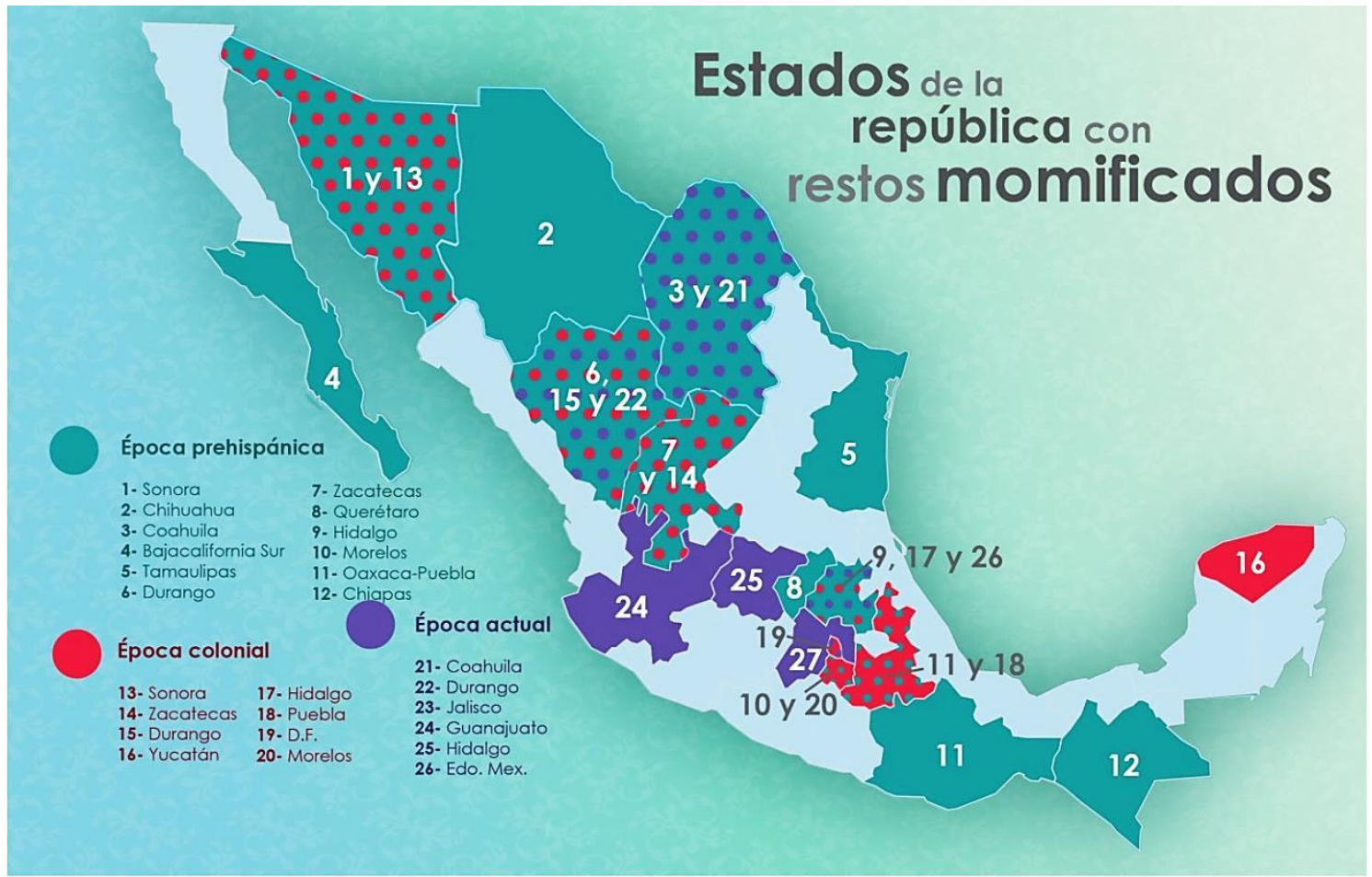

Fuente: Judith Ruiz

Figura 4. Ejemplo de momificación de la época prehispánica. Pepita, la momia de la Sierra Gorda de Querétaro, de hace 2300 años de antigüedad, antes del presente. Se aprecian restos de textil, plumas de ave y trenzas de cabello humano

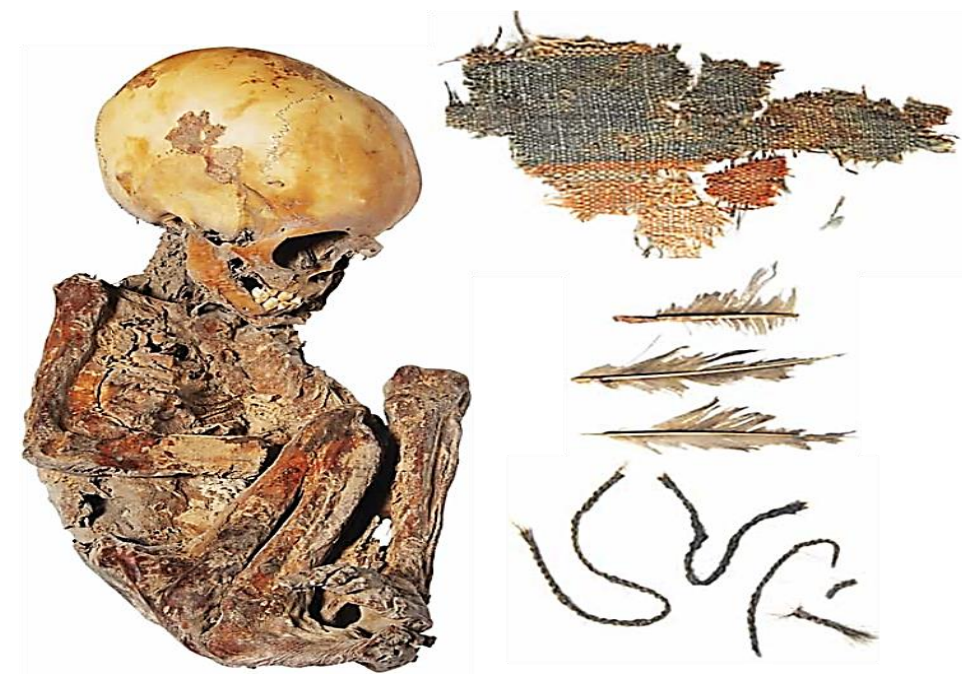

Fuente: Mejía-Pérez et al. (2009). 
Figura 5. Ejemplo de momificación correspondiente a la época novohispana. Momia de un niño de Tlayacapan, Morelos

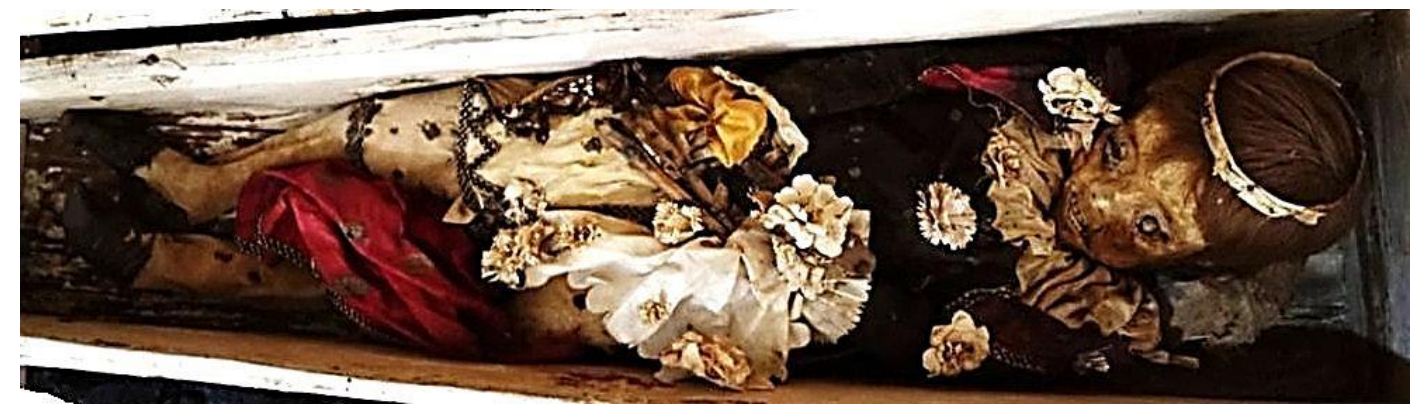

Fuente: Judith Ruiz González.

Figura 6. Ejemplo de momificación actual. Cuerpo momificado de Candelario Plascencia Días. Galería de momias en Zapopan, Guadalajara

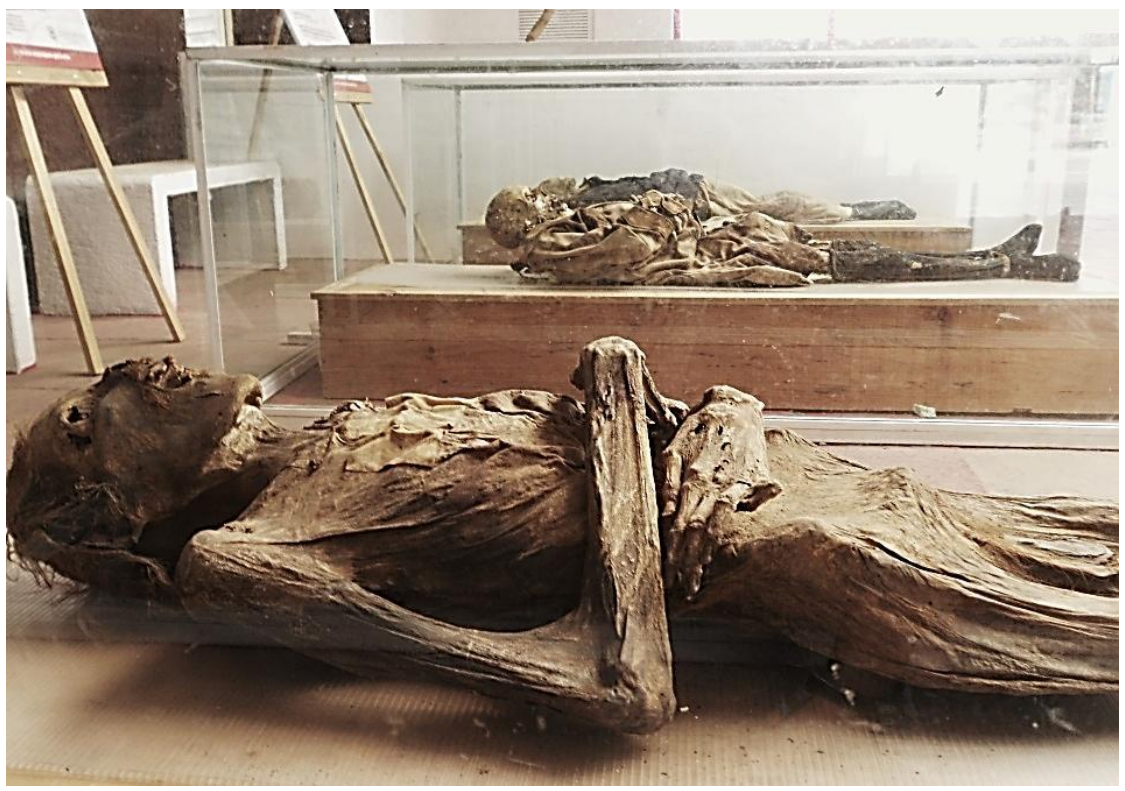

Fuente: Judith Ruiz González.

En las figuras 4, 5 y 6 se ven ejemplos de momificaciones por época. El tipo de momificación más común es la natural, pero también se encuentran casos de momificación natural inducida y de la artificial o antrópica. Sobre la momificación natural inducida se tiene noticia por los documentos históricos de la época de la inquisición en México, los cuales mencionan la guerra de las autoridades seculares contra los adoratorios que guardaban los bultos funerarios de gobernantes momificados de coras y huicholes en la región del Gran Nayar, durante el siglo XVIII (Malvido, 2003; Neurath, 2008).

Los hallazgos de restos momificados en México se deben a motivos fortuitos tales como saqueo, donación y, en pocos casos, descubrimientos bajo proyectos arqueológicos. Su temporalidad abarca la época prehispánica, la colonial y la actual. La mayoría provienen de sitios con clima árido o semiárido y fueron encontrados en cuevas, sobre todo en el norte del país, o en los subsuelos de templos que datan del siglo XVI, así como en tumbas verticales construidas en algunos atrios de iglesias contemporáneas, en panteones o cementerios municipales. Cabe señalar que actualmente existen dos acervos de restos 
momificados provenientes de varios sitios, ambos en la Dirección de Antropología Física del INAH.

\section{El hallazgo arqueológico de las momias de Tlayacapan}

En mayo de 1982, durante el proyecto de consolidación y remodelación de la iglesia de San Juan Bautista con la intención de recuperar las estructuras originales del piso, los trabajadores encontraron tres entierros momificados bajo el subsuelo del inmueble, con sus respectivos ataúdes de madera policromada y en perfecto estado de conservación. Uno de ellos estaba localizado en la parte izquierda de la puerta principal (entierro 1), y los otros dos, en el centro de la nave (entierros 4 y 10). Se trata de tres individuos infantiles (figura 7).

En el transcurso del mismo mes se dio parte a las autoridades del INAH-Morelos para que se llevara a cabo una excavación adecuada. La labor se inició el 27 de mayo, con término al 30 de julio del mismo año. Durante la exploración se localizaron 39 entierros humanos, de los cuales 23 se dejaron en el sitio de hallazgo debido al grado de deterioro que mostraban. Ocho de los entierros se reinhumaron en el atrio de la iglesia, y los nueve restos momificados restantes se exhiben hoy día en el refectorio de este antiguo edificio colonial, en compañía de objetos recuperados en la exploración y de arte sacro agustino (Oliveros, 1990).

Figura 7. Plano de distribución de la planta baja del convento de San Juan Bautista. En amarillo el área de excavación y la ubicación de los tres entierros localizados en un inicio; en rojo la sala de exhibición

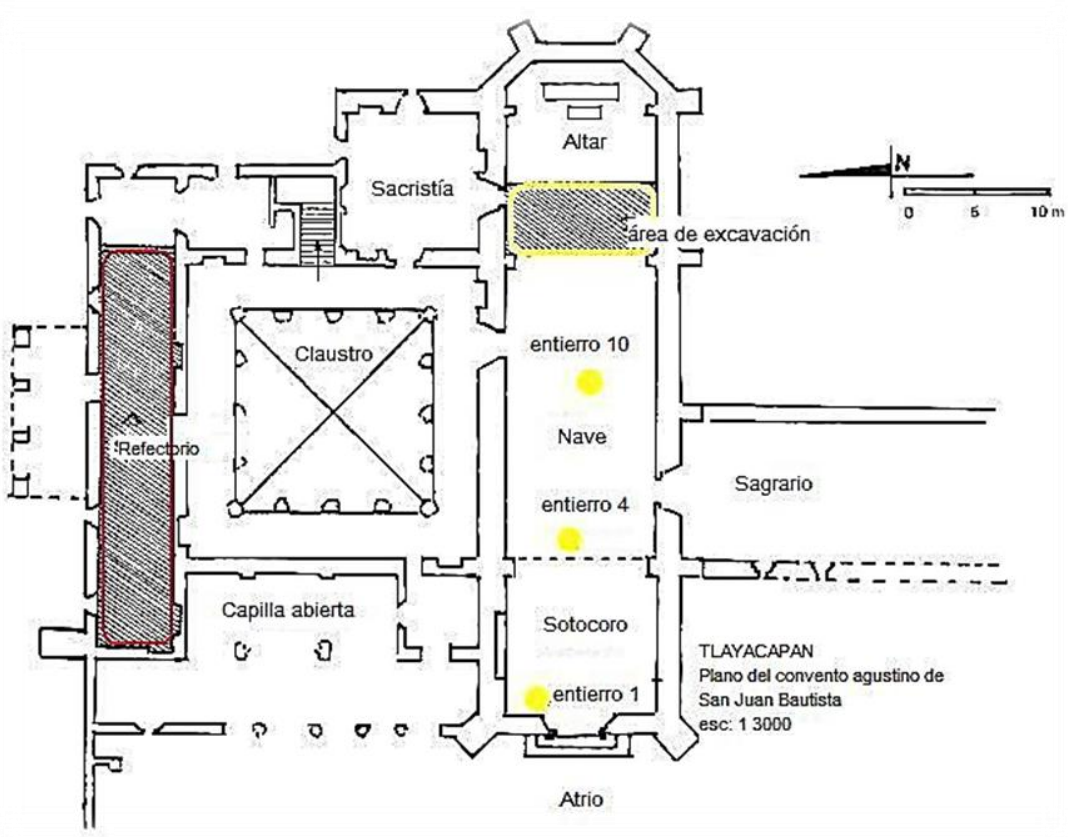

Fuente: (Oliveros, 1990).

El área de excavación se limitó al presbiterio, una superficie de 5,50 m por $14 \mathrm{~m}$ de ancho de la nave en donde se recuperaron 10 cráneos y varios huesos largos (falanges y clavículas), fragmentos de ataúd, entre otros elementos, además de los entierros antes señalados. Estos hallazgos indican la reutilización del espacio para sepultar entierros por un largo periodo. 
En la exhumación se diferenciaron tres niveles de entierro, a 1,60 m de profundidad máxima, en los que se localizaron 36 entierros. En estos niveles se detectaron diferencias de conservación y superposición cronológica de restos. Así, en el primer nivel, que corresponde al más antiguo, se encontraron diez entierros $(11,14,19,23,24$ y 34-38), la mayoría en mal estado de conservación, con presencia de restos de madera pulverizada; ninguno de ellos se movió de lugar.

En el segundo nivel se identificaron 18 entierros $(5,8,9,12,13,15-18,25,26,28-33$ y 39) en regular y buen estado de conservación, con indicios de momificación parcial o completa, algunos con restos de piel o cuero cabelludo. En este caso se volvieron a enterrar casi todos los féretros y sus contenidos. Asimismo, varios ataúdes de este nivel se encontraban rotos parcial o totalmente debido a la superposición de cajas incrustadas de enterramientos más recientes del nivel tres. Tal es el caso del entierro 26, que corresponde a don Juan Sánchez, y el entierro 27 localizado arriba de él (figura 8). Esta característica es prueba de una simultaneidad de los sepulcros o de que existían lugares reservados para los fallecidos pertenecientes a una familia.

El tercer nivel y más superficial lo conforman 11 entierros $(1-4,6,7,10,20-23$ y 27) en buen estado de conservación y momificación, que pertenecen, en su mayoría, a infantes de ambos sexos.

Todos los entierros manifiestan la misma orientación, de este a oeste, con la cabeza hacia el altar y más levantada que los pies, depositados en decúbito dorsal extendido, es decir, boca arriba, con los brazos extendidos o sobre el regazo y los pies juntos o uno sobre el otro (Oliveros, 1990).

Figura 8. Área de excavación, distribución de los entierros en los tres niveles y forma de los ataúdes

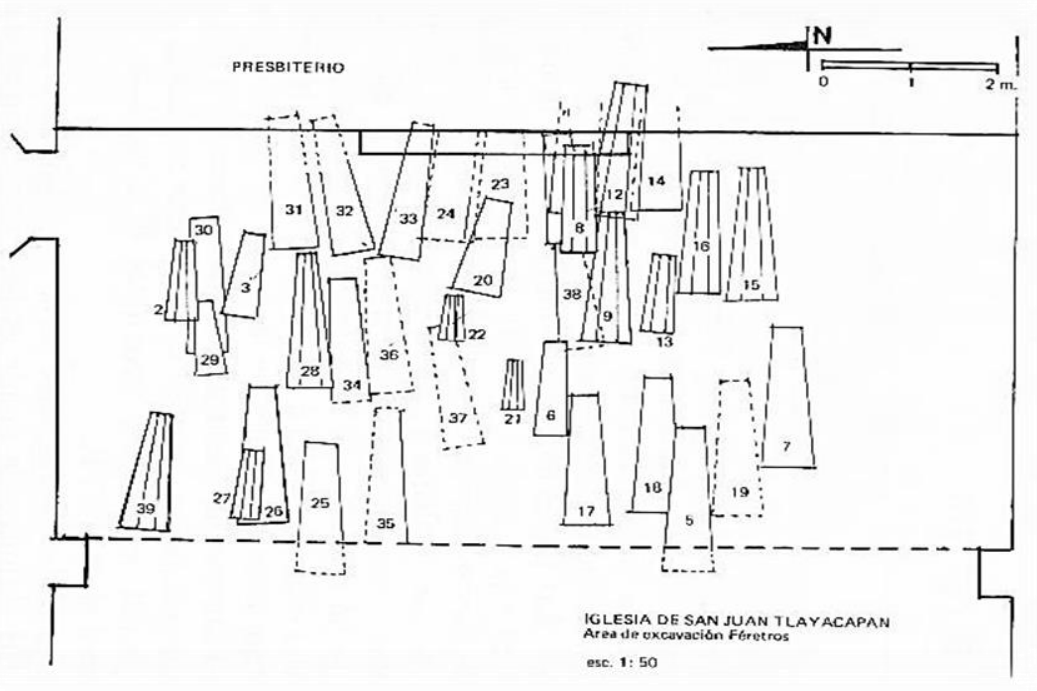

Fuente: Oliveros (1990).

En la figura 8 se puede apreciar la distribución de los entierros en el presbiterio, la superposición de algunos entierros de niveles superiores con el anterior, y la forma y variedad de estilos de ataúd: con tapa plana y de forma piramidal. En las figuras 9, 10 y 11 se observan algunas de las momias evaluadas para este estudio. 
Figura 9. Momia infantil 1

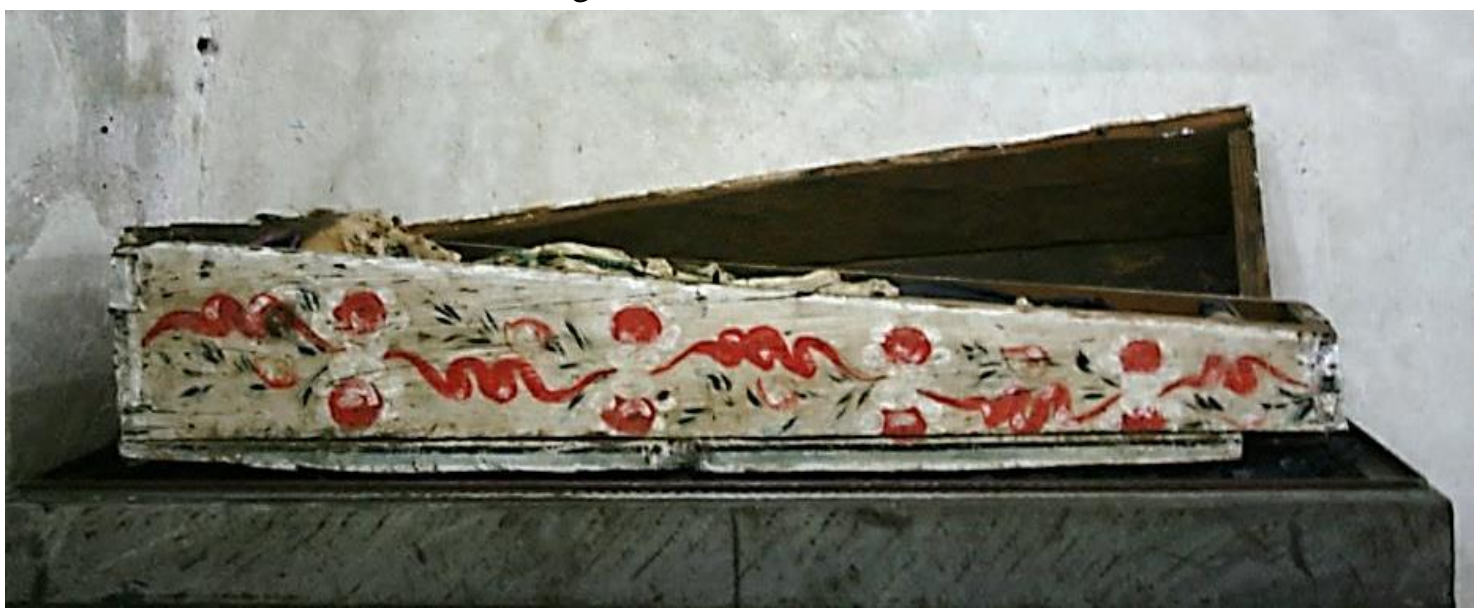

Fuente: Judith Ruiz.

Figura 10. Momia 6, perteneciente al entierro 10. Se aprecia tipo de vestimenta, posición del cuerpo y decoración del ataúd

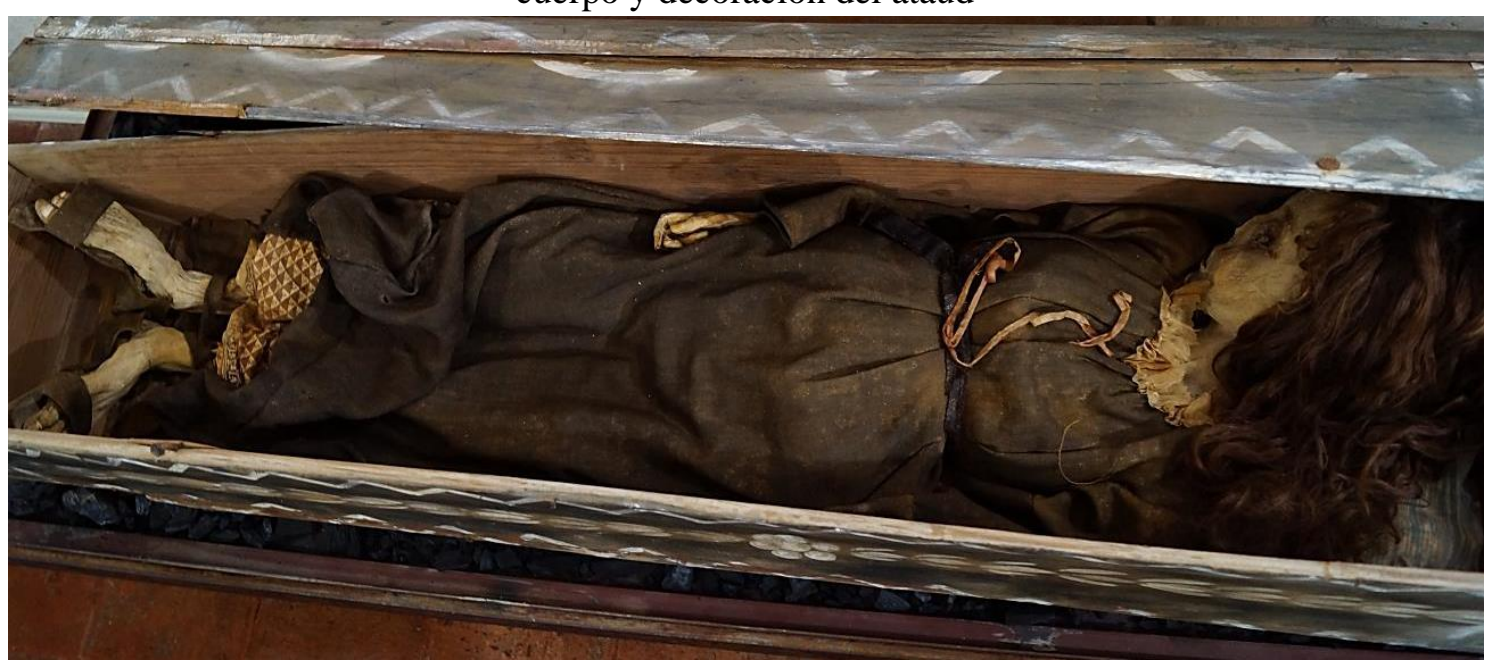

Fuente: Judith Ruiz.

Figura 11. Momia número 3. Se aprecia tipo de vestimenta y forma del ataúd

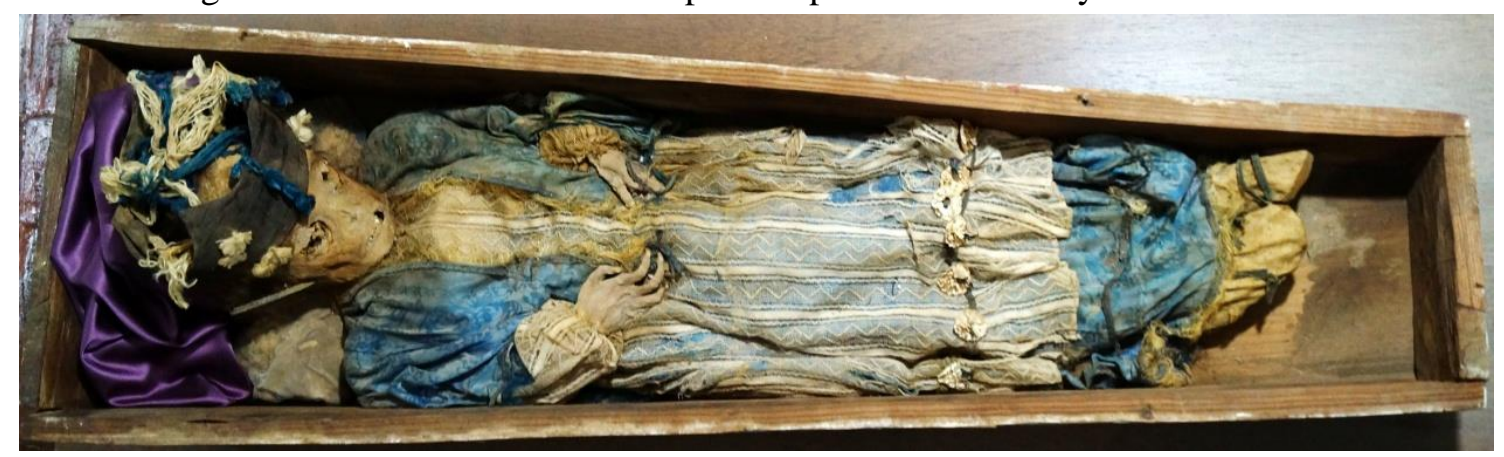

Fuente: Judith Ruiz.

Ruiz-González, J. L, Serrano-Sánchez, C. (2020). Imagenología aplicada a las momias de Tlayacapan, Morelos, México. Jangwa Pana 19(1), 45 - 84. DOl: https://doi.org/10.21676/16574923.3357 


\section{Materiales y métodos}

Son nueve las momias que conforman este estudio: ocho individuos infantiles y un individuo adulto, resguardados actualmente en el exconvento de Tlayacapan, Morelos (figura 12).

Figura 12. Distribución de las momias en la sala de exhibición, refectorio, y la numeración asignada

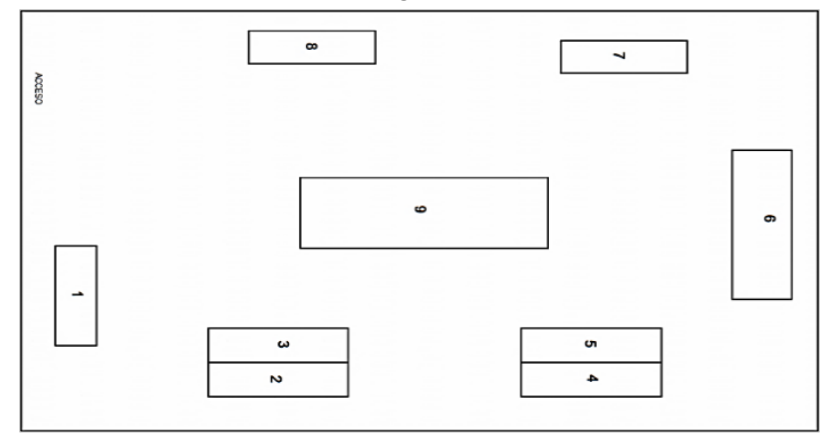

Fuente: elaboración propia.

Para el conocimiento de las condiciones de vida, se recurrió al modelo de estrés ${ }^{4}$ y los determinantes de la salud (Goodman y Martin, 2002; Frenk, Bobadilla, Stern, Frejka y Lozano, 1991). Desde este punto de vista, la biología humana está sujeta a transformaciones por la interacción en una misma unidad sinérgica. Así, el esqueleto humano y la dentición son considerados como sistemas abiertos, dinámicos, históricos y adaptativos, que a lo largo de su vida in utero hasta la muerte han estado en constante interacción con el ambiente natural y social y, por lo mismo, sufren modificaciones a nivel fisiológico - y en casos severos a nivel morfológico- en respuesta a las diferentes presiones o estímulos ocasionados por el contexto socioambiental en que se encuentra inmerso el individuo (Luna, 2006). Por ello es importante que la evaluación de las condiciones de salud y nutrición se explique a partir de la información histórica sociocultural.

Para que ocurra un episodio de estrés intervienen de forma sinérgica tres factores: las restricciones ambientales, el sistema sociocultural y la resistencia individual; de modo que no es posible identificar la causa última del proceso de disrupción fisiológica. Por estrés se entiende una alteración fisiológica en el organismo ocasionada por la incidencia de diversos factores medioambientales sobre él — patógenos, ambientales, infecciosos o autogenerados- El estrés puede ser medible y tiene consecuencias en los individuos y las poblaciones, pero el factor estresante específico es rara vez conocido, y la respuesta fisiológica ya no es directamente observable (Goodman y Martin, 2002); sin embargo, hay una variedad de cambios esqueléticos que son usados para entender el estrés, el impacto individual y la adaptación de la población a su medio (Goodman y Martin, 2002, p. 17).

Si los estresores no son atenuados, ocurre un estrés biológico observable en el tejido óseo y dental. Además, así como el medio ambiente, la cultura desempeña un doble papel en el estado de salud, ya que puede mitigar o, en su defecto, producir el estrés; es el caso de

\footnotetext{
${ }^{4}$ Efectos fisiológicos que se manifiestan a nivel óseo como respuesta adaptativa del organismo ante situaciones adversas, como son: líneas de Harris, hipoplasias del esmalte, hiperostosis porótica, enfermedades infecciosas, traumatismos, patologías bucales y padecimientos osteoarticulares (Goodman y Martin, 2002).
} 
situaciones de desigualdad en el acceso a los recursos básicos para la sobrevivencia humana. La persistencia de las condiciones estresantes resulta en la disminución de la salud y del estatus nutricional, que se ven comprometidos aún más por la exposición a los mismos estresores. Por ejemplo, un individuo con nutrición pobre es menos resistente a las enfermedades infecciosas, y a su vez la presencia de enfermedades infecciosas disminuye aún más el estado nutricional (Goodman y Martin, 2002). Ante una situación de estrés durante la niñez, una de las consecuencias más importantes que se reflejan posteriormente es la alteración del crecimiento normal, desde una detención momentánea hasta un cambio sustancial del ritmo de dicho proceso (Rose et al., 1985, en Luna, 2006:258).

De esta manera se entiende que es imposible conocer la etiología de los indicadores de estrés, y por ello se consideran no específicos. Ahora, si bien debido a su naturaleza multifactorial poseen una utilidad restringida a nivel causal, sí permiten evaluar las condiciones de vida de los grupos del pasado. Los indicadores evaluados al respecto son los siguientes:

- Indicadores de estrés general acumulado:

- Datos paleodemográficos: edad y sexo.

- Evaluación del crecimiento y desarrollo: basados en la proposición de que la reducción de la velocidad del crecimiento o el decremento de este es la respuesta del organismo a distintos niveles de estrés.

- Indicadores de estrés episódico:

- Líneas de Harris, transversales o bandas de densidad incrementada: son líneas densas transversales observables en los huesos largos a través de imagenología o histología. Aparecen como resultado de un periodo previo de estrés.

- Traumatismos: son causados por fuerzas físicas o por contacto con objetos punzocortantes. Su análisis se debe hacer en relación con el sexo y la edad del individuo afectado, además de sus condiciones de salud. Este tipo de lesiones también pueden causar reacciones periostales, con inflamación de tipo infeccioso.

- Padecimientos osteoarticulares: se refiere a las alteraciones que sufren las articulaciones por diversos factores: el proceso de envejecimiento, el tipo de trabajo realizado, el medio ambiente, el tipo de dieta, traumatismos, entre otros. De este tipo de padecimientos, el más común es la osteoartritis, que afecta directamente el cartílago articular. Su consecuencia, además del dolor, es la invalidez que provoca en la persona, pues limita su movilidad.

Para llevar a cabo este estudio fue preciso aplicar la imagenología, en específico de los rayos $\mathrm{X}$, que es una herramienta que está siendo aprovechada en diversas áreas de conocimiento y conservación de los bienes culturales. Se optó entonces por la radiología de campo, debido al estado de conservación de los bienes que se iban a radiografiar, por sus características de tamaño y porque la instancia donde se resguardan no permite su traslado fuera del lugar donde se encuentran ubicados. 


\section{El proceso de toma radiográfica}

La toma radiográfica de los nueve cuerpos momificados de Tlayacapan se llevó a cabo in situ, en el área del refectorio de la edificación conventual. Cabe señalar que no fue posible evaluar todos los indicadores de estrés porque a través de los rayos X solo se obtienen imágenes en escala de grises con diferente intensidad tonal y no se logra observar detalladamente la superficie morfológica del hueso. Así, aunque siempre es recomendable realizar este tipo de estudios en un laboratorio de radiología, en esta ocasión solo fue posible llevar a cabo la radiología de campo. Afortunadamente, existen diversos tipos y modelos de aparatos que pueden ser adaptados según las necesidades de los usuarios. Es así como pueden utilizarse aparatos tanto fijos como portátiles; estos últimos son de gran utilidad en la radiología de campo.

El equipo utilizado para esta investigación fue proporcionado por el Laboratorio de Osteología del Instituto de Investigaciones Antropológicas de la UNAM, y fue el siguiente:

- Equipo portátil Toshiba Torex Rayos X Serie Tr 20, calibrado a 60 kV, 5 mA y a tres segundos de exposición.

- Tanques de revelado y de fijado, y uno para agua.

- Líquido revelador y líquido fijador de película de rayos X, Kodak, GBX.

- Anteojos especiales, mandil, cuello y guantes emplomados.

- Ganchos para sostener las placas reveladoras.

- Chasis de metal con pantalla intensificadora Lanex Fast Screens de Kodak, tamaño 24 x $30 \mathrm{~cm}$ y $20,3 \times 25,4 \mathrm{~cm}$.

- Películas Kodak, tamaño 20,3 x 25,4 cm y 24 x $30 \mathrm{~cm}$.

- Bata, guantes y tapaboca desechable.

Las radiografías se tomaron en la sala de exhibición (refectorio) de la edificación conventual donde se encuentran los nueve restos momificados. El museo no dio servicio por este día y se desalojó el área de trabajo (figura 13). El cuarto de revelado manual se instaló en un área retirada y de pequeñas dimensiones, y se acondicionó con los requerimientos y medidas de seguridad necesarios. Para la aplicación de rayos X, las momias fueron colocadas con sus respectivos ataúdes $y$, debido a su tamaño, se radiografiaron en dos o tres segmentos en posición anteroposterior: cabeza-cuello-tóraxhombro y pelvis-extremidades inferiores, respetando la manera en que fueron enterradas, decúbito dorsal extendido. Se mantuvo un metro de distancia entre la fuente de rayos $\mathrm{X}$ y la placa, y cada momia fue ubicada lo más próximo al chasis metálico que guarda la película con un tiempo de exposición de tres segundos (figura 13).

La calidad de las radiografías, de acuerdo a la clasificación de las placas (Vila-Gay, 1997, p. 83), en algunos casos se considera dura y, en otros, correcta, pero sobre todo es útil, pues revela información aprovechable para la valoración requerida ${ }^{5}$. Para la digitalización de las radiografías se utilizaron un negatoscopio y una cámara fotográfica Canon EOS Digital Rebel Xti/18-55 mm.

\footnotetext{
${ }^{5}$ La calidad radiográfica se ha clasificado en: blanda, cuando el objeto radiografiado se muestra de forma blanquecina y no se aprecia estructura ósea; dura, cuando el objeto radiografiado se muestra de forma oscura y tiene pérdida de estructura ósea; correcta, cuando el objeto radiografiado se muestra nítido, bien representado, con buena visualización de la estructura ósea, y útil cuando, en el caso de radiografías blandas o duras, permiten el examen preciso de una zona concreta (Vila-Gay, 1997, p. 83-84).
} 
Figura 13. Sala de exhibición en el Museo de San Juan Bautista y toma de radiografías

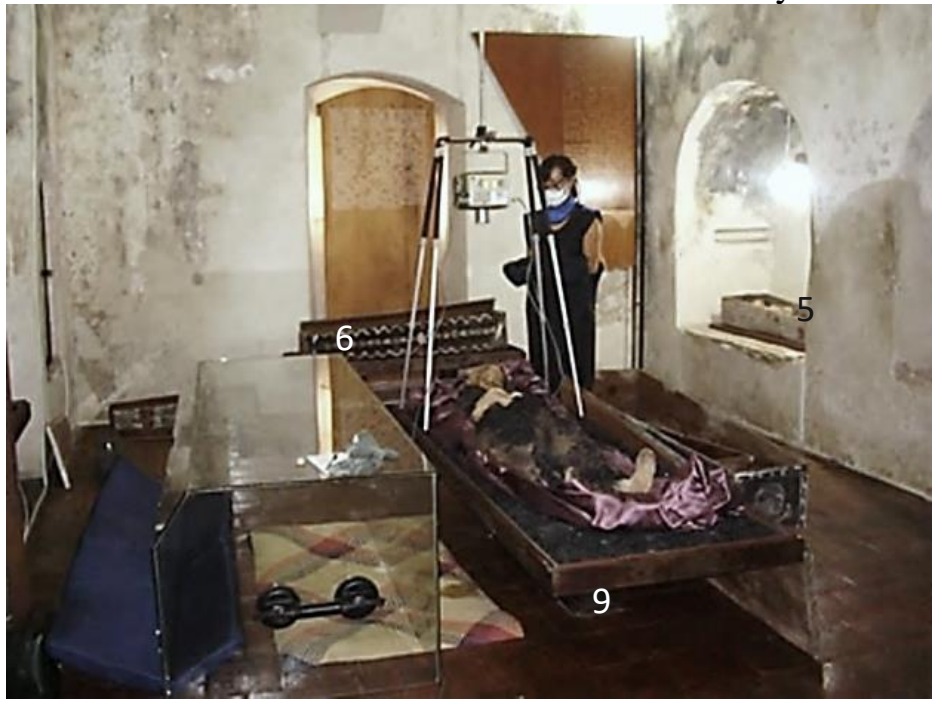

Fuente: Jorge Gómez Valdés.

\section{Resultados}

La aplicación de rayos X en las momias de Tlayacapan confirmó que se trata de esqueletos recubiertos con piel, además de cabello y uñas, pero no son visibles los órganos internos ${ }^{6}$. Esta ausencia puede deberse a que la desecación ocurrió después de la descomposición de estos órganos como consecuencia del avance de la putrefacción cadavérica.

En la tabla 1 se proporciona una síntesis de los hallazgos del análisis efectuado en las momias, los cuales se desglosarán más adelante. En principio, cabe anotar que fue posible apreciar que algunos huesos no se encuentran en posición anatómica, quizás porque las momias han sido manipuladas, movidas o trasladadas varias veces desde el momento de su hallazgo (figura 14). De las nueve momias, siete (1, 2, 4, 5, 7, 8 y 9) muestran huesos o segmentos óseos desarticulados y fuera de lugar (figura 14). También se pudieron identificar elementos como alambres o lentejuelas, que son parte del atavío de los difuntos, así como clavos de hierro forjado para unir las tablas de los ataúdes. Además, se observaron ornamentos como los señalados en las figuras 15 y 16.

\footnotetext{
${ }^{6}$ Es posible que con la aplicación de otras técnicas se logre la visualización de los órganos internos.
} 

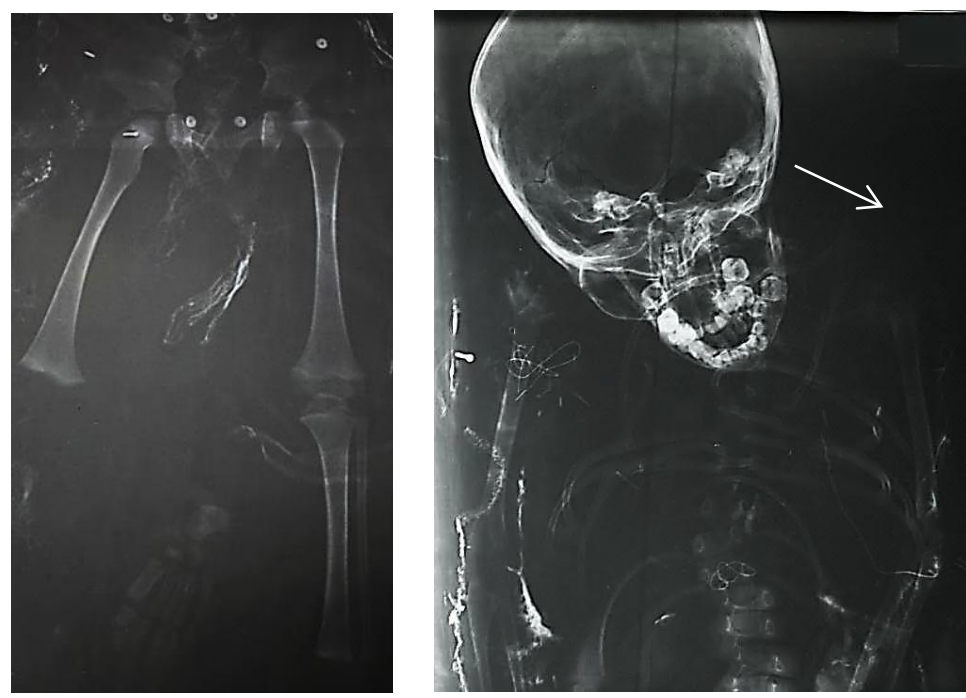

Figura 14. Izquierda: momia infantil 8. Se aprecia ausencia de tibia y peroné derechos, así como pie izquierdo fuera de lugar. Derecha: momia infantil 7. Se aprecia vértebra cervical en cráneo y caja torácica desarticulada Fuente: Judith Ruiz y Jorge Gómez Valdés.

Figura 15. Vista anteroposterior del dorso de la momia 6, donde se observan objetos de metal, entre ellos un broche.
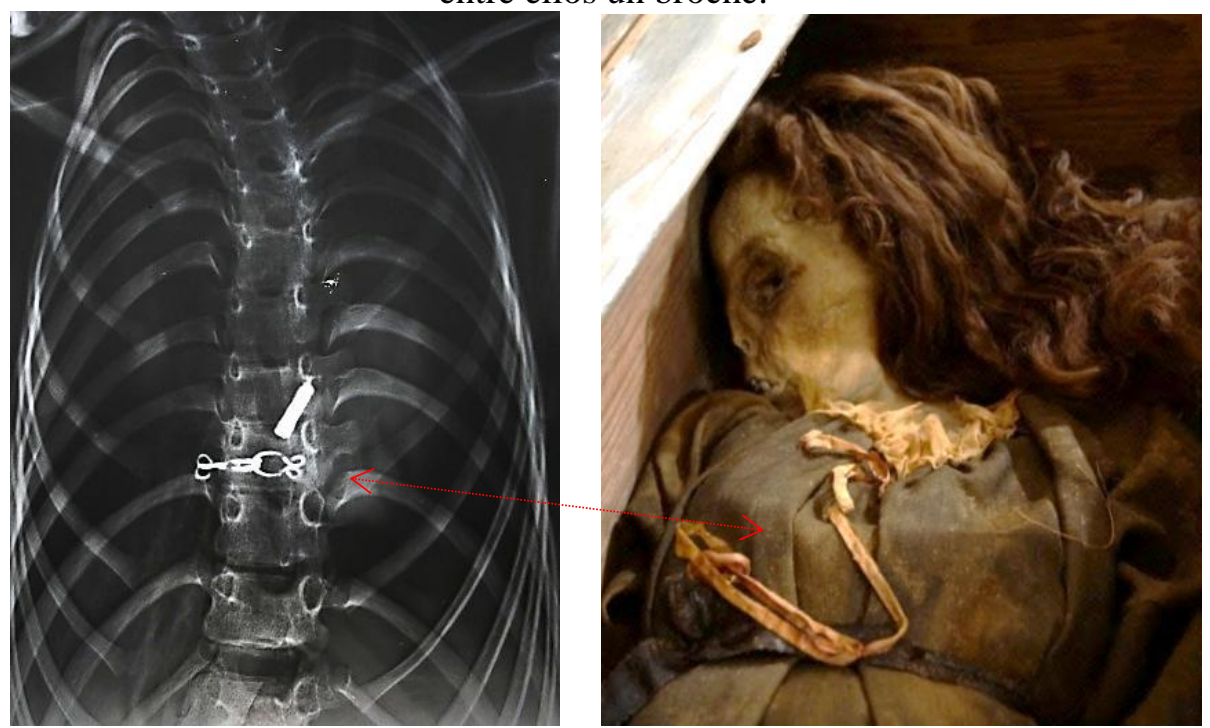

Fuente: Judith Ruiz y Jorge Gómez Valdés.

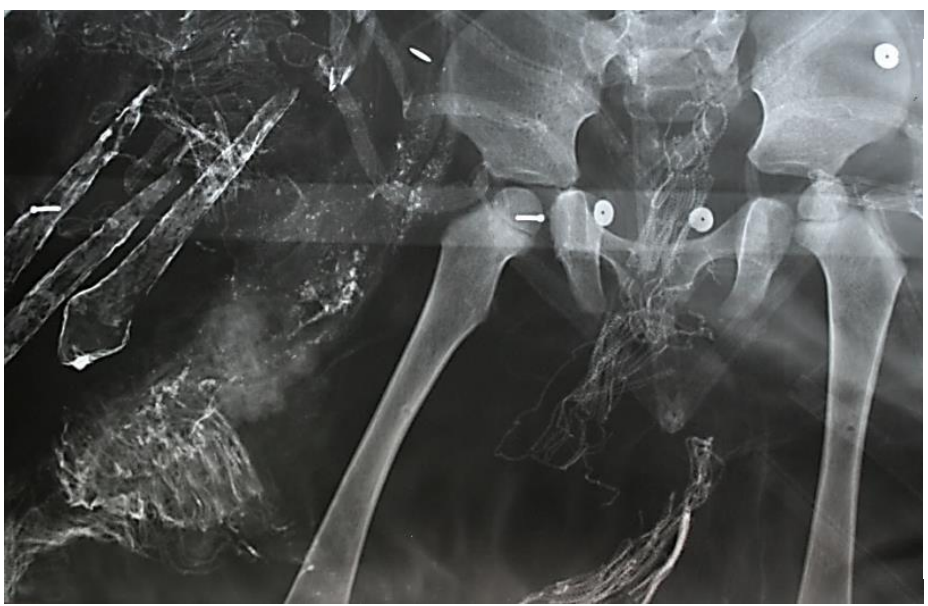

Figura 16. Vista anterior de la pelvis de momia 8. Se observa mapa de luces y sombras, con elementos más opacos como los adornos de alambre y la lentejuela, que son parte del atavío del individuo, además de tres clavos de madera recubiertos de plata o estaño, que simbolizan el Padre, el Hijo y el Espíritu Santo

Fuente: Judith Ruiz y Jorge Gómez Valdés. 
Jangwa Pana Vol. 19(1) | año | e-ISSN 2389-7872 | ISSN 1657-4923

\begin{tabular}{|c|c|c|c|c|c|c|c|c|c|}
\hline \multirow[t]{2}{*}{ Momia } & \multirow{2}{*}{$\begin{array}{c}\text { Segmentos } \\
\text { desarticulado } \\
\text { s }\end{array}$} & \multirow[t]{2}{*}{ Sexo } & \multicolumn{3}{|c|}{ Edad } & \multirow{2}{*}{$\begin{array}{l}\text { Rango de } \\
\text { edad } \\
\text { (años) }\end{array}$} & \multirow{2}{*}{$\begin{array}{c}\text { Estatura } \\
\text { estimada }(\mathrm{cm})\end{array}$} & \multirow{2}{*}{$\begin{array}{l}\text { Líneas de } \\
\text { Harris }\end{array}$} & \multirow{2}{*}{$\begin{array}{c}\text { Traumatismo peri } \\
\text { mortem }\end{array}$} \\
\hline & & & $\begin{array}{l}\text { Calcificación } \\
\text { dental (años) }\end{array}$ & $\begin{array}{l}\text { Brote } \\
\text { dental }\end{array}$ & $\begin{array}{l}\text { Osificación, fusión } \\
\text { y articulación de } \\
\text { rodilla (años) }\end{array}$ & & & & \\
\hline 1 & Sí & Masculino & - & $\begin{array}{c}4 \\
\text { años/ } \pm 12 \\
\text { meses }\end{array}$ & 3,5 & 3,5 a 4 & 79,0 & Sí & No \\
\hline 2 & Sí & Femenino & 6,3 & $\begin{array}{c}6 \\
\text { años/ } \pm 24 \\
\text { meses }\end{array}$ & 6 a 6,5 & 6 a 6,5 & 107,3 & Sí & Sí \\
\hline 3 & No & Masculino & 4,8 & $\begin{array}{c}5 \\
\text { años/ } \pm 16 \\
\text { meses }\end{array}$ & 4,5 & 4,5 a 5 & 95,4 & Sí & No \\
\hline 4 & Sí & Masculino & $>3$ & $\begin{array}{c}2 \text { años } / \pm 8 \\
\text { meses }\end{array}$ & 2 & 2 a 2,5 & 75,1 & No & Sí \\
\hline 5 & Sí & Masculino & - & $\begin{array}{c}5 \\
\text { años/ } \pm 16 \\
\text { meses }\end{array}$ & 4,5 & 4,5 a 5 & 86,4 & No & No \\
\hline 6 & No & Femenino & 7,5 & $\begin{array}{c}8 \\
\text { años/ } \pm 24 \\
\text { meses }\end{array}$ & 7,5 a 8 & 7,5 a 8,5 & 123,6 & Sí & No \\
\hline 7 & Sí & Masculino & 7 & $\begin{array}{c}6 \\
\text { años/ } \pm 24 \\
\text { meses }\end{array}$ & 6,5 & 6,5 a 7 & $90-91$ & Sí & No \\
\hline 8 & Sí & Masculino & $>3$ & $\begin{array}{l}18 \text { meses- } \\
2 \text { años } \pm 8 \\
\text { meses }\end{array}$ & 1,5 & 1 a 1,5 & 75,7 & No & Sí \\
\hline 9 & Sí & Masculino & - & - & - & $45-55$ & 1,65 & No & Sí \\
\hline
\end{tabular}




\section{Sexo y edad}

Al emplear radiografías en momias cabe tener en cuenta que en la calidad de las imágenes intervienen factores como la superposición de imágenes y la posición que ostenta el individuo, que en ocasiones dificulta la visualización correcta de los segmentos óseos en examen.

Para la asignación del sexo en individuos subadultos se aplicaron varias técnicas que ya han sido probadas para estos fines (Hernández-Espinosa y Peña-Reyes, 2010, p. 13, 33) y en las que se evalúan los caracteres morfoscópicos en mandíbula y pelvis (LópezAlonso, 1971; Hernández-Espinosa y Peña-Reyes, 2010, p. 13, 33). En el caso de los adultos, se evalúan rasgos en el cráneo, la mandíbula y la cintura pélvica, además de las inserciones musculares (Buikstra y Ubelaker, 1994).

Las nueve momias de Tlayacapan cuentan con vestimenta religiosa típica de la época colonial. En algunos casos el sexo de los individuos parecía ambiguo debido a que el atuendo, en su mayoría, se trata de batas y de faldones debajo de ellas, en compañía de adornos en la cabeza, como coronas o diademas, de manera que la ropa no denota el sexo; por lo tanto, esta característica se debió corroborar de acuerdo a los métodos antes mencionados. De manera que para identificar el sexo en las momias se hizo uso de las radiografías tomadas en el área de la pelvis y de la mandíbula, en su vista anterior. Vale anotar al respecto que, aunque la posición general del individuo era decúbito dorsal extendido, algunos segmentos óseos, como la cabeza, se encontraron rotados hacia otra dirección. En el caso de la pelvis, el ángulo de $45^{\circ}$ que proyecta en su vista posterior imposibilitó la evaluación de algunos de los rasgos mencionados.

En la mandíbula se evaluó solo un rasgo debido a la posición en la que se encuentra en todas las momias, que difiere en cada individuo. Dicho rasgo evaluado fue la forma del mentón o protusión mandibular: en los hombres se observa mentón cuadrado y proyectado hacia adelante, y en las mujeres, más redondeado o con ausencia de protusión (figura 17) (Sutter, 2003, en Hernández-Espinosa y Peña-Reyes, 2010).

Figura 17. Izquierda: mandíbula de individuo masculino, donde se observa mentón cuadrado (momia 3). Derecha: mandíbula de individuo masculino, donde se observa proyección hacia el frente del mentón (momia 8)

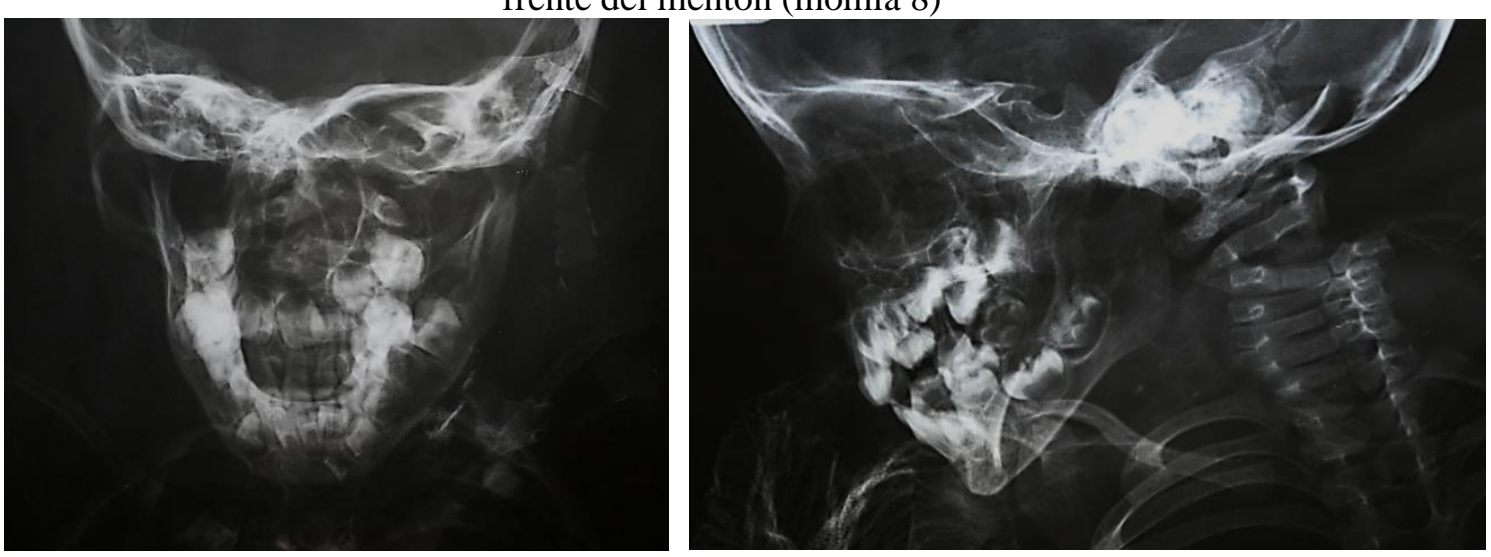

Fuente: Judith Ruiz y Jorge Gómez Valdés.

Los rasgos evaluados en la pelvis fueron: el ángulo subpúbico, abierto (en forma de U invertida) o cerrado (en forma de $\mathrm{V}$ invertida); el ángulo de la escotadura ciática, abierto 
o cerrado; características de la región del pubis, como la ausencia o presencia de la cresta en la superficie medial del pubis y la ausencia o presencia de la concavidad subpúbica (López-Alonso, 1971; Phenice, 1969; en Hernández-Espinosa y Peña-Reyes, 2010). De acuerdo a lo anterior, de las nueve momias, dos son femeninas (los números 2 y 6), y el resto son masculinas (figura 18).

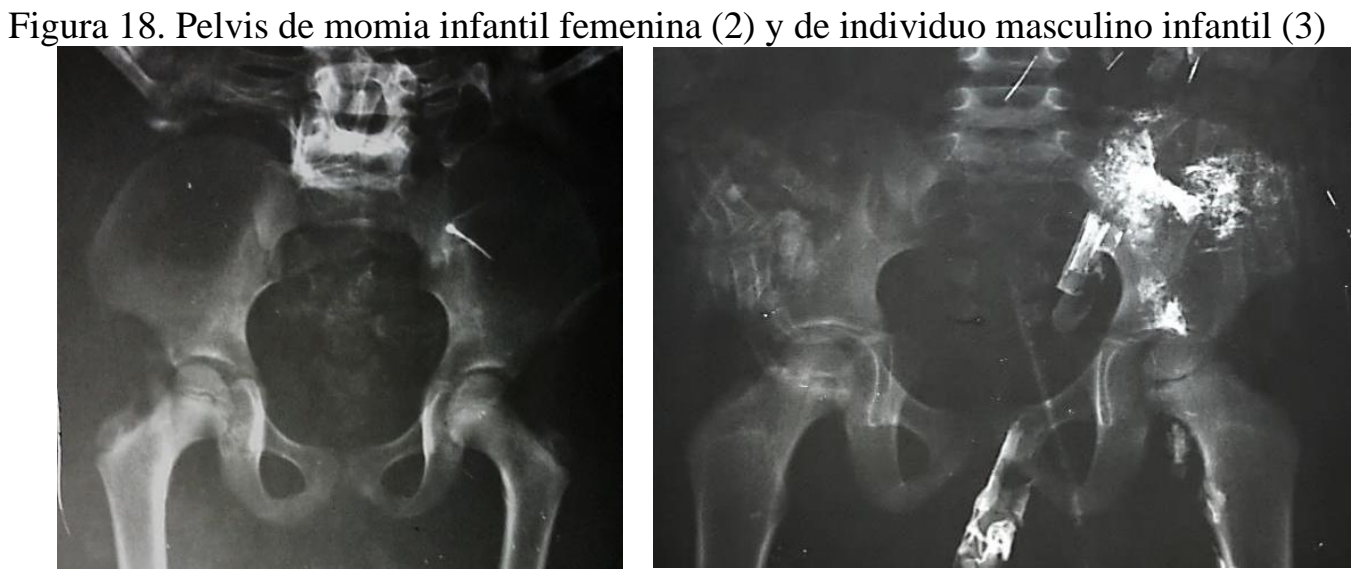

Fuente: Judith Ruiz y Jorge Gómez Valdés.

Para estimar la edad se emplearon los siguientes métodos: calcificación en el desarrollo dental; formación o erupción de brote dental; aparición de centros de osificación en epífisis proximal de húmero y pelvis y fusión de centros óseos en pelvis, epífisis proximal de fémur y calcáneo, e indicadores de madurez en articulación de rodilla izquierda (Demirjian, Goldstein y Tanner, 1973; Schaefer, Black y Scheuer, 2009; Ubelaker, 1989).

Es importante señalar que, al valorar el progreso de las características de crecimiento o dentición hacia el estado adulto, las cuales difieren en el ritmo de maduración a nivel individual y poblacional, el estatus de crecimiento varía entre individuos que podrían tener la misma edad cronológica a la muerte (Peña y Esquivel, 1989, en Peña-Reyes, Hernández-Espinosa y Márquez-Morfín, 2007, p. 154). Esto se explica, además, por el hecho de que aplicar un método de referencia que no es cercano a la población de estudio puede dar lugar a sesgos o, en este caso, desfases en términos del ritmo de crecimiento, como en el caso del método de Demirjian et al. (1973) con el desarrollo dental. Este es un problema cuando no se generan métodos de referencia locales, por lo que siempre los resultados deben tomarse con cautela. Así las cosas, se propone un rango de edad de los individuos, más que una edad cronológica.

1. Estadios de calcificación en el desarrollo dental (Demirjian et al., 1973). Para este método se requiere una radiografía panorámica. En este caso se utilizan ocho estadios de desarrollo, cada uno representado por una letra, de la $\mathrm{A}$ a la $\mathrm{H}$, evaluados en siete dientes mandibulares que deben apreciarse individualmente y en orden: M2, M1, PM2, PM1, C, IL, IC. Se valora desde el inicio de la calcificación en las cúspides hasta el momento del cierre del ápice y se consideran los cambios en la longitud desde la corona hasta la raíz (figura 19).

Una vez que se asignan los estadios, cada uno de ellos se convierte en valores numéricos, cuya suma dará un valor que se ubica entre 0 y 100. Esta puntuación se convertirá en la edad dental que corresponda (Peña-Reyes y González-Álvarez, 2010: 15-16) según la tabla 2. 


\begin{tabular}{|c|c|c|c|c|c|c|c|c|c|c|}
\hline \multicolumn{2}{|c|}{ Momia } & \multicolumn{7}{|c|}{ Piezas dentales evaluadas } & \multirow[t]{2}{*}{ Suma } & \multirow[t]{2}{*}{ Edad dental (años) } \\
\hline & & M2 & M1 & PM2 & PM1 & $\mathrm{C}$ & $\mathrm{IL}$ & IC & & \\
\hline \multirow[t]{2}{*}{ 1/M } & Estadio & \multirow{2}{*}{\multicolumn{9}{|c|}{ No es posible evaluar por la posición de la mandíbula }} \\
\hline & Valor & & & & & & & & & \\
\hline \multirow[t]{2}{*}{$2 / \mathbf{F}$} & Estadio & $\mathrm{B}$ & $\mathrm{D}$ & $\mathrm{C}$ & $\mathrm{E}$ & $\mathrm{E}$ & $\mathrm{E}$ & $\mathrm{E}$ & \multirow[t]{2}{*}{42} & \multirow[t]{2}{*}{6,3} \\
\hline & Valor & 3,9 & 4,5 & 6,5 & 11,8 & 7,3 & 5,6 & 2,4 & & \\
\hline \multirow[t]{2}{*}{$3 / \mathbf{M}$} & Estadio & $\mathrm{B}$ & $\mathrm{D}$ & A & $\mathrm{B}$ & $\mathrm{D}$ & $\mathrm{E}$ & $\mathrm{E}$ & \multirow[t]{2}{*}{23,8} & \multirow[t]{2}{*}{4,8} \\
\hline & Valor & 3,5 & 8 & 1,7 & 0 & 3,5 & 5,2 & 1,9 & & \\
\hline \multirow[t]{2}{*}{$4 / M$} & Estadio & \multirow{2}{*}{\multicolumn{9}{|c|}{ No es posible evaluar por la posición de la mandíbula }} \\
\hline & Valor & & & & & & & & & \\
\hline \multirow[t]{2}{*}{ 5/M } & Estadio & \multirow{2}{*}{\multicolumn{9}{|c|}{ No es posible evaluar por la posición de la mandíbula }} \\
\hline & Valor & & & & & & & & & \\
\hline \multirow[t]{2}{*}{$6 / F$} & Estadio & $\mathrm{C}$ & $\mathrm{G}$ & $\mathrm{D}$ & $\mathrm{D}$ & $\mathrm{D}$ & $\mathrm{G}$ & $\mathrm{G}$ & \multirow[t]{2}{*}{64,3} & \multirow[t]{2}{*}{7,5} \\
\hline & Valor & 6,9 & 14,0 & 10,6 & 7,5 & 3,8 & 12,2 & 9,3 & & \\
\hline \multirow[t]{2}{*}{$7 / \mathrm{M}$} & Estadio & $\mathrm{E}$ & $\mathrm{F}$ & $\mathrm{E}$ & $\mathrm{D}$ & $\mathrm{D}$ & $\mathrm{C}$ & $\mathrm{C}$ & \multirow[t]{2}{*}{47,3} & \multirow[t]{2}{*}{7} \\
\hline & Valor & 12,5 & 12,3 & 12 & 7 & 3,5 & 0 & 0 & & \\
\hline \multirow[t]{2}{*}{$8 / \mathbf{M}$} & Estadio & A & $\mathrm{D}$ & - & - & B & B & $\mathrm{C}$ & \multirow[t]{2}{*}{10,1} & \multirow[t]{2}{*}{$>3$} \\
\hline & Valor & 2,1 & 8,0 & - & - & 0 & 0 & 0 & & \\
\hline
\end{tabular}

F: femenino. M: masculino.

Fuente: elaboración propia.

Figura 19. Radiografía dental de la momia 6 en vista lateral derecha (edad dental estimada de

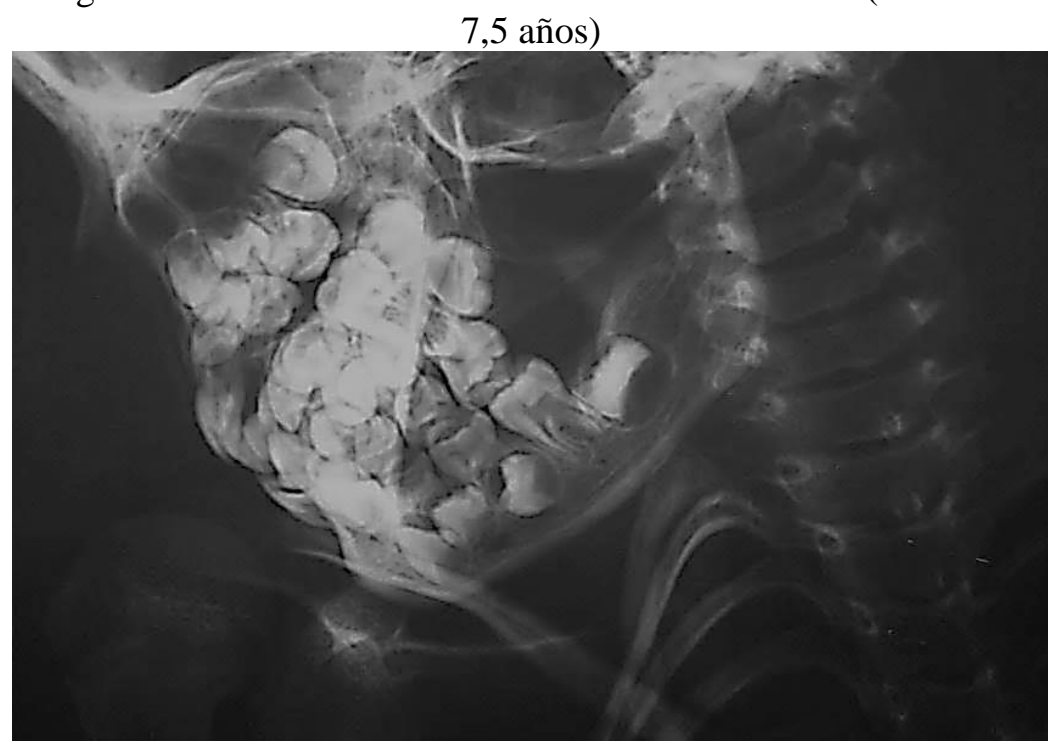

Fuente: Judith Ruiz y Jorge Gómez Valdés.

2. Formación y erupción o brote dental. Ubelaker (1989) propuso una tabla de desarrollo dental para poblaciones amerindias, la cual está dividida en 22 etapas 
asociadas a edades específicas, donde se observa la secuencia en la formación y erupción de los dientes (Krenzer, 2006).

3. Aparición de centros de osificación en epífisis proximal de húmero y pelvis, y fusión de centros óseos en cráneo, vértebras, pelvis, epífisis proximal de fémur y calcáneo. Este método permite estimar un rango de edad en las momias, pues solo se puede cuantificar presencia, ausencia, desarrollo y unión de las epífisis (Schaefer, Black y Scheuer, 2009).

4. Indicadores de madurez en articulación de rodilla izquierda (fémur, tibia y peroné). Se estima a través de una imagen radiográfica anteroposterior de la articulación. En este método se evalúan las proporciones, la morfología, la presencia o ausencia de ciertos indicadores y el grado de fusión en las epífisis y metáfisis. Los indicadores que se presentan de acuerdo con cierta edad están diferenciados por sexo (Roche, Wainer y Thissen, 1975).

En la tabla 3 se presenta la edad estimada en las momias a partir de la calcificación de los dientes, el brote dental, la aparición de centros de osificación y fusión, así como el grado de madurez en rodilla. En cuanto a la calcificación dental, no fue posible evaluarla en los ocho individuos debido a que la posición del rostro imposibilitó la visión de todas las piezas dentales para su valoración.

\begin{tabular}{|c|c|c|c|c|c|c|}
\hline 串 & Sexo & $\begin{array}{l}\text { Calcificación } \\
\text { dental (años) }\end{array}$ & $\begin{array}{l}\text { Brote } \\
\text { dental }\end{array}$ & $\begin{array}{l}\text { Osificación, } \\
\text { fusión y } \\
\text { articulación } \\
\text { de rodilla } \\
\text { (años) }\end{array}$ & $\begin{array}{c}\text { Rango de } \\
\text { edad } \\
\text { (años) }\end{array}$ & $\begin{array}{c}\text { Categoría de } \\
\text { edad } \\
\text { (Krenzer, } \\
\text { 2006) }\end{array}$ \\
\hline 1 & Masculino & - & $\begin{array}{c}4 \text { años } / \pm 12 \\
\text { meses }\end{array}$ & 3,5 & 3,5 a 4 & 1. ${ }^{\mathrm{a}}$ infancia \\
\hline 2 & Femenino & 6,3 & $\begin{array}{c}6 \text { años/ } \pm 24 \\
\text { meses }\end{array}$ & 6 a 6,5 & 6 a 6,5 & 1. ${ }^{\mathrm{a}}$ infancia \\
\hline 3 & Masculino & 4,8 & $\begin{array}{c}5 \text { años } / \pm 16 \\
\text { meses }\end{array}$ & 4,5 & 4,5 a 5 & 1. ${ }^{\mathrm{a}}$ infancia \\
\hline 4 & Masculino & $>3$ & $\begin{array}{c}2 \text { años } / \pm 8 \\
\text { meses }\end{array}$ & 2 & 2 a 2,5 & 1. ${ }^{\mathrm{a}}$ infancia \\
\hline 5 & Masculino & - & $\begin{array}{c}5 \text { años } / \pm 16 \\
\text { meses }\end{array}$ & 4,5 & 4,5 a 5 & 1. ${ }^{\mathrm{a}}$ infancia \\
\hline 6 & Femenino & 7,5 & $\begin{array}{c}8 \text { años } \$ 24 \\
\text { meses }\end{array}$ & 7,5 a 8 & 7,5 a 8,5 & 2. ${ }^{\mathrm{a}}$ infancia \\
\hline 7 & Masculino & 7 & $\begin{array}{c}6 \text { años } / \pm 24 \\
\text { meses }\end{array}$ & 6,5 & 6,5 a 7 & 2. ${ }^{a}$ infancia \\
\hline 8 & Masculino & $>3$ & $\begin{array}{c}18 \text { meses-2 } \\
\text { años/ } \pm 8 \\
\text { meses }\end{array}$ & 1,5 & 1 a 1,5 & 1. ${ }^{\mathrm{a}}$ infancia \\
\hline
\end{tabular}

Fuente: elaboración propia.

Como ya se ha mencionado, la edad biológica estimada a partir de los huesos no refleja la edad cronológica precisa del individuo. Esto conlleva un cierto margen de error, 
causado por la variabilidad biológica del crecimiento y de la madurez ósea, pues no todos los organismos se comportan de la misma manera.

La edad biológica se encuentra influenciada por una serie de factores intrínsecos y extrínsecos: la influencia genética, enfermedades, estrés ocupacional, actividades físicas, medio ambiente, recursos o alimentación, filiación étnica y diferentes velocidades del desarrollo (ontogénesis). Además, este parámetro puede ser más exacto en individuos que no han alcanzado la madurez o adultos jóvenes que en adultos, ya que en los huesos es posible apreciar y valorar los estadios de madurez en sus diferentes periodos.

\section{Estimación de la edad en adultos}

Para estimar la edad biológica en el individuo adulto se visualizaron segmentos óseos clavícula, húmero y fémur- a través de rayos X, como se describirá enseguida (tabla 4).

1. Observaciones radiográficas en la clavícula (Walker y Lovejoy, 1985). La clavícula es el mejor hueso para estimar la edad sin importar el sexo del individuo. Este reconocimiento se basa en una serie de cambios trabeculares en la metáfisis esternal y lateral hasta llegar a la pérdida sistemática del tejido óseo, bajo el supuesto de que, a mayor edad, mayor traslucidez y trabeculación. Los cambios están representados por ocho fases, que van desde los 18 años hasta personas mayores de 55 años.

2. La estructura esponjosa del húmero y del fémur (Acsádi y Nemeskéri, citado por Herrmann et al., 1990, en Krenzer, 2006: 55-57). Para este caso se pueden utilizar radiografías, tomografías computarizadas o cortes verticales de huesos secos. El método se basa en la evaluación de cambios trabeculares en la cavidad medular en seis etapas, que describen las diferencias en la estructura esponjosa de ambos huesos.

En la tabla 4 se aprecia el rango de edad que se llegó a estimar para la momia 9 a partir de los cambios trabeculares de clavícula, húmero y fémur (figura 20).

\begin{tabular}{|c|c|}
\hline \multicolumn{2}{|c|}{ Tabla 4. Edad de momia 9, individuo adulto masculino } \\
\hline Métodos empleados & Momia 9/individuo masculino \\
\hline 1.Cambios trabeculares en clavícula & Fase VI: 45-49 años \\
\hline 2. Cambios trabeculares en húmero & Etapa 3: $<40$ años \\
\hline 2.1 Cambios trabeculares en fémur & Etapa 5: $<50$ años \\
\hline \multicolumn{2}{|c|}{ Rango de edad: 45-55 años } \\
\hline
\end{tabular}

Fuente: elaboración propia. 


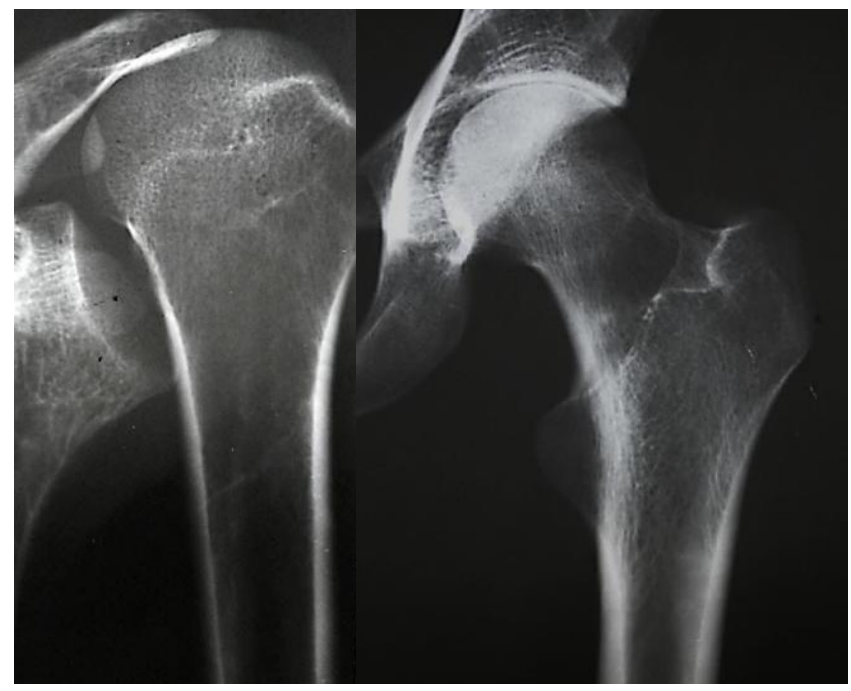

Figura 20. Húmero izquierdo y fémur izquierdo con cambios trabeculares (momia 9)

Fuente: Judith Ruiz y Jorge Gómez Valdés.

De acuerdo a las categorías de edad utilizadas en estudios antropológicos, seis momias se encuentran dentro de la primera infancia, dos corresponden a la segunda infancia, y la momia 9 es un individuo masculino en la etapa de adulto maduro.

\section{Estimación de crecimiento}

El crecimiento es el resultado de complejas interacciones entre los genes y las condiciones que ofrece el ambiente donde ocurren estos procesos a lo largo del ciclo vital (Peña-Reyes, Hernández-Espinosa y Márquez-Morfín, 2007, p. 153). Específicamente, intervienen varios factores: biológicos, ambientales, sociales, culturales y económicos. Así, además de ser un indicador general del tamaño corporal, el crecimiento también permite evaluar los cambios en la calidad de vida y en las condiciones de salud de un individuo.

El estatus de crecimiento para este estudio se basa en la estatura que se estimó a partir de la longitud diafisiaria de fémur utilizando el método de Maresh (1963, en HernándezEspinosa y Peña-Reyes, 2010: 84), con la siguiente ecuación regresiva: Estatura $=\mathrm{Fx} 0,002+\mathrm{Fx} 2,972+359,41 \pm 124$. También fue posible obtener la estatura a través de la medición de la longitud total del cuerpo de la momia, como se muestra en la tabla 5 .

Además de conocer la talla alcanzada hasta el momento de la muerte, también es importante el estatus de crecimiento, toda vez que proporciona información sobre las condiciones de vida que experimentaron los individuos. Para conocer dicho parámetro, se tomaron como referencia los datos del estudio longitudinal de crecimiento realizado por Faulhaber-Kamman (1976) en una muestra de niños mestizos con mayor componente blanco de la Ciudad de México, correspondientes a la clase media de la sociedad, y se eligieron los valores de media por grupo de edad y la desviación estándar de estatura para cada edad según el sexo. La edad que se empleó para seleccionar la referencia es tanto la dental como la esquelética, y se considera que existió un retardo en el crecimiento de los individuos del presente estudio cuando la estatura de las momias se ubica dos desviaciones estándar por debajo de lo esperado para la edad y el sexo en el grupo de referencia (tabla 6). 
Tabla 5. Estatura estimada para las momias de Tlayacapan

\begin{tabular}{|c|c|c|c|c|c|c|}
\hline Momia & $\begin{array}{c}\text { Estatura } \\
\text { corporal } \\
(\mathrm{cm})\end{array}$ & $\begin{array}{c}\text { Longitud } \\
\text { diafisiaria } \\
(\mathrm{cm})\end{array}$ & $\begin{array}{c}\text { Máxima } \\
\text { Maresh } \\
(1963)\end{array}$ & $\begin{array}{c}\text { Mínima } \\
\text { Maresh } \\
(1963)\end{array}$ & $\begin{array}{c}\text { Media } \\
\text { Maresh } \\
(1963)\end{array}$ & $\begin{array}{c}\text { Estatura } \\
\text { estimada } \\
(\mathrm{cm})\end{array}$ \\
\hline 1 & 75 & 14,5 & 914,64 & 666,64 & 790,64 & 79,0 \\
\hline 2 & 106 & 24 & $\begin{array}{c}1 \\
197,17\end{array}$ & 949,17 & 1 & 107,3 \\
& & & 1 & 830,21 & 954,17 & 95,4 \\
\hline 3 & 95 & 20 & 078,21 & & & \\
\hline 4 & 73 & 13,2 & 875,978 & 627,978 & 751,978 & 75,1 \\
\hline 5 & 87 & 17 & 988,99 & 740,99 & 864,99 & 86,4 \\
\hline 6 & 122 & 29,5 & 1 & 1 & 1 & 123,6 \\
\hline 7 & 89 & - & - & - & - & $90-91$ \\
\hline 8 & 70 & 13,4 & 881,926 & 633,926 & 757,926 & 75,7 \\
\hline 9 & 165 & - & - & - & - & 1,65 \\
\hline
\end{tabular}

Tabla 6. Estatura esperada según el grupo de referencia

\begin{tabular}{|c|c|c|c|}
\hline Momia & $\begin{array}{c}\text { Edad } \\
\text { biológica }\end{array}$ & $\begin{array}{c}\text { Estatura } \\
\text { estimada }(\mathrm{cm})\end{array}$ & $\begin{array}{c}\text { Estatura esperada } \\
\text { Faulhaber (1976) } \\
(\mathrm{cm})\end{array}$ \\
\hline 1/masculino & 3,5 & $79,0 /-4 \mathrm{ds}$ & 96,38 \\
\hline 2/femenino & $\mathbf{6}$ & $\mathbf{1 0 7 , 3 / - 1 d s}$ & $\mathbf{1 1 1 , 0 6}$ \\
\hline 3/masculino & 4,5 & $95,4 /-2 \mathrm{ds}$ & 103,24 \\
\hline 4/masculino & 2 & $75,1 /-2 \mathrm{ds}$ & 85,59 \\
\hline 5/masculino & 4,5 & $86,4 /-3 \mathrm{ds}$ & 103,24 \\
\hline 6/femenino & $\mathbf{8}$ & $\mathbf{1 2 3 , 6}$ & $\mathbf{1 2 2 , 4 5}$ \\
\hline 7/masculino & 6,5 & $90-91 /-5 \mathrm{ds}$ & 116,35 \\
\hline $\mathbf{8 / m a s c u l i n o}$ & $\mathbf{1 , 5}$ & $\mathbf{7 5 , 7} / \mathbf{- 1 d s}$ & $\mathbf{7 9 , 9 1}$ \\
\hline
\end{tabular}

De acuerdo a estos datos, algunas de las momias de Tlayacapan presentan un retardo en el crecimiento (momias 1, 4, 5 y 7), con edades a la muerte de 2 a 6,5 años y con -2 desviaciones estándar o más respecto al grupo de referencia. Las momias que se considera no fueron afectadas en su crecimiento son las 2,6 y 8.

Como se indicó, si bien el reloj biológico regula los procesos de crecimiento y maduración, estos pueden ser modificados por influencias ambientales -condiciones de vida - que intervienen o favorecen la expresión del potencial genético heredado. El proceso de crecimiento, en particular, ayuda a conocer si existe una alteración a nivel biológico y en uno de los aspectos claves asociados a él: la nutrición y el ambiente; sobre todo, permite determinar si existió una dieta deficiente, con episodios de enfermedades sufridas durante la infancia y la adolescencia, que pudo retrasar el desarrollo físico y, por ende, generar una talla terminal reducida (Tiesler, 2001). En ese orden de ideas, un retardo en el crecimiento puede asociarse a condiciones de vida adversas, severas dificultades de salud y/o desnutrición después del nacimiento, e incluso a un retardo en el crecimiento intrauterino que el individuo no logró recuperar en la vida posnatal. 
A excepción de los individuos más pequeños - momias 4 y 8 -, se puede decir que los demás infantes sobrevivieron a la etapa más mórbida, antes de los tres años de vida, adaptándose al ambiente extrauterino y superando los problemas generados por la inmadurez del recién nacido. Después de esta edad ya hay mayor estabilidad en el sistema inmunológico y las probabilidades de sobrevivencia van en aumento (Peña-Reyes, Hernández-Espinosa y Márquez-Morfín, 2007). Ahora bien, pese a ello, los individuos de las momias no lograron sobrevivir a periodos posteriores.

En el caso del individuo adulto (momia 9), la estatura se obtuvo por la medición de la longitud total del cuerpo $(165 \mathrm{~cm})$ y se comparó con la media de la estatura reportada en otros estudios realizados en muestras coloniales, como se presenta en la tabla 7.

\begin{tabular}{|c|c|c|c|}
\hline \multicolumn{4}{|c|}{ Tabla 7. Media de la estatura masculina en muestras coloniales } \\
\hline Momia $9^{1}$ & ${\text { Catedral'72 } 72^{2}}^{2}$ & Tlatelolco & $\mathrm{HRN}^{3}$ \\
\hline $165 \mathrm{~cm}$ & $164 \mathrm{~cm}$ & $162 \mathrm{~cm}$ & $159,03 \mathrm{~cm}$ \\
\hline
\end{tabular}

HRN: Hospital Real de los Naturales.

Fuente: ${ }^{1}$ presente estudio; ${ }^{2 M a ́ r q u e z-M o r f i ́ n ~(1984) ; ~}{ }^{3}$ Ruiz-González (2011); ${ }^{4}$ Castillo-Chávez (2000).

En la tabla 7 se aprecia que la estatura de la momia 9 es similar a la muestra de Catedral' 72 (Catedral Metropolitana) y difiere con las medias de Tlatelolco y del Hospital Real de los Naturales. La muestra de la catedral corresponde españoles y criollos de la élite de la sociedad novohispana del siglo XVI hasta el siglo XIX; en el caso de Tlatelolco, se trata de individuos mestizos que pertenecieron a un sector popular de dicho barrio, y la muestra del Hospital Real de los Naturales proviene de gente que murió en esta institución, predominantemente indígena, correspondiente al sector pobre de la población.

\section{Indicadores de estrés}

Es importante señalar que el modelo de estrés de Goodman y Martin (2002) se propone evaluar a nivel óseo varios indicadores. Sin embargo, no fue posible aplicarlo completamente en las momias porque estas no se pudieron manipular para observar morfológicamente la superficie de los dientes y de los huesos en general, como ocurre con los restos esqueléticos. Por lo tanto, el modelo fue adaptado al estudio de las condiciones de salud en restos momificados.

\section{Líneas de Harris}

La fisis es el principal centro para el crecimiento longitudinal y la expansión circunferencial de los huesos largos, incluidas las falanges. Está formada de cartílago, que madura con rapidez en los huesos de las extremidades, se colapsa continuamente y es reemplazado por hueso durante el crecimiento. Así pues, es visible antes de alcanzar el tamaño adulto, y posteriormente es reabsorbida y reemplazada por un hueso que une la epífisis de manera permanente con la metáfisis (Terry-Canale, 2000) (figura 21). 


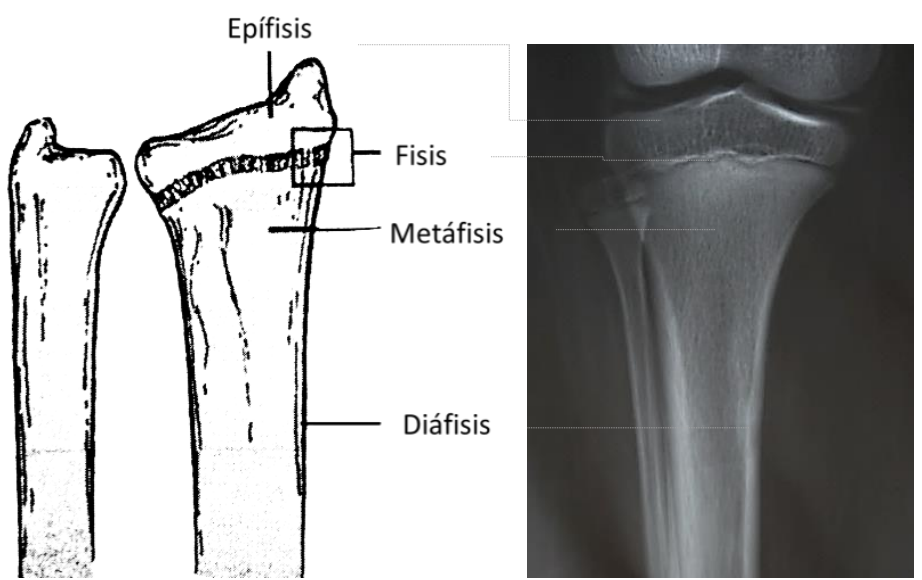

Figura 21. Izquierda: diagrama tomado de Terry-Canale (2000, p. 18). Derecha: articulación de rodilla izquierda de la momia 6

La consecuencia de una lesión fisiaria es la interrupción del crecimiento longitudinal del hueso, ya sea completa o parcial, con la aparición de líneas de refuerzo o bandas óseas ${ }^{7}$. Cuando el cese del crecimiento es completo, hay una desigualdad en longitud de los miembros con compromiso funcional, sin crecimiento adicional; y cuando es parcial ocurren deformidades angulares o un acortamiento progresivo, lento y gradual del crecimiento. En general, los signos clínicos de la formación de una barra ósea son la deformidad angular y el acortamiento de la extremidad afectada (Terry-Canale, 2000; Hesinger, 2000) $)^{8}$.

Sobre la incidencia de estas líneas transversales, Resnick (2001: 912-915) menciona que es un hallazgo radiográfico frecuente en niños y adultos, y además que se pueden encontrar tanto en personas sanas como en enfermas. Pueden estar presentes durante el nacimiento o la lactancia y no aparecen después de que el crecimiento ha concluido, pero una vez formadas persisten en la edad adulta.

Por su ubicación y semejanza con los platillos de crecimiento, estas líneas se han asociado a una alteración del patrón normal del crecimiento, pero se trata, más bien, de líneas de recuperación de crecimiento, porque indican periodos de crecimiento acelerado o renovado que aparecen después de una etapa de inhibición del crecimiento óseo, y pueden verse como una variante normal en casos de estrés previo. Por ejemplo, se manifiestan tras la intoxicación por metales pesados o en las fases de curación de la leucemia, el raquitismo y el escorbuto, así como por hipotiroidismo, hipervitaminosis D y, también, infecciones trasplacentarias: rubéola, citomegalovirus, herpes simple, toxoplasmosis y sífilis.

De las nueve momias que se presentan en este estudio, en cinco de ellas es posible apreciar líneas de Harris en los huesos largos. La frecuencia de líneas no es tan alta y sobre todo se presentan en tibia, seguidas del fémur, el radio y el peroné. El individuo que cuenta

\footnotetext{
${ }^{7}$ Estas líneas también son conocidas como de detención del crecimiento, líneas densas, líneas de refuerzo óseo, barras óseas, líneas transversales o de estrés de Park o de Harris. Se asocian con episodios de enfermedad o de lesión en niños y adolescentes y se presentan en los huesos largos luego de fracturas diafisiarias. La alteración de estas lesiones es menos problemática para aquellos que las sufren cerca de finalizar su crecimiento. A pesar de que comúnmente se las asocia con un daño de las células fisiarias debido a fracturas, no se conoce con claridad su patogénesis y en muchas ocasiones no poseen causas aparentes.

${ }^{8}$ Las líneas de refuerzo son bandas de trabéculas de grosor variable que se extienden parcial o completamente a través de la cavidad medular en los huesos tubulares (Resnick, 2001). El número de líneas puede variar en longitud y espesor con el paso del tiempo debido a la remodelación constante que sufre el hueso durante la primera etapa de la vida.
} 
con mayor número de líneas es la momia 1 (figuras 22 y 23). Se describe cada caso en la tabla 8 .

\begin{tabular}{|c|c|c|}
\hline \multicolumn{3}{|c|}{ Tabla 8. Presencia de líneas de Harris en las momias } \\
\hline Momia & Hueso y localización & Descripción \\
\hline 1 & $\begin{array}{l}\text { Epífisis distal de ambos radios } \\
\text { Epífisis distal de fémures } \\
\text { Epífisis proximal y distal de tibias y } \\
\text { peronés }\end{array}$ & $\begin{array}{l}\text { Se presentan de tres a cinco líneas } \\
\text { consecutivas de la metáfisis a diáfisis, que } \\
\text { llegan a ser parciales o completas. }\end{array}$ \\
\hline 2 & $>$ Epífisis distal de fémures & $\begin{array}{l}\text { Se presentan de tres a cuatro líneas } \\
\text { consecutivas en el centro de la metáfisis a } \\
\text { diáfisis, que llegan a ser parciales y oblicuas. }\end{array}$ \\
\hline 3 & $>$ Epífisis proximal de tibia izquierda & $\begin{array}{l}\text { Se presentan dos líneas parciales } \\
\text { consecutivas en la metáfisis. }\end{array}$ \\
\hline 6 & $\begin{array}{l}\text { En diáfisis de tibias, hacia la parte } \\
\text { distal }\end{array}$ & $\begin{array}{l}\text { Se presenta una línea completa a la misma } \\
\text { altura en ambos huesos. }\end{array}$ \\
\hline 7 & $>$ En epífisis distal de radio izquierdo & $\begin{array}{l}\text { Se presentan dos líneas completas } \\
\text { consecutivas en la metáfisis. }\end{array}$ \\
\hline
\end{tabular}

Fuente: elaboración propia.

Figura 22. Líneas de Harris en epífisis distal de fémures y epífisis proximal de tibias (momia 1)

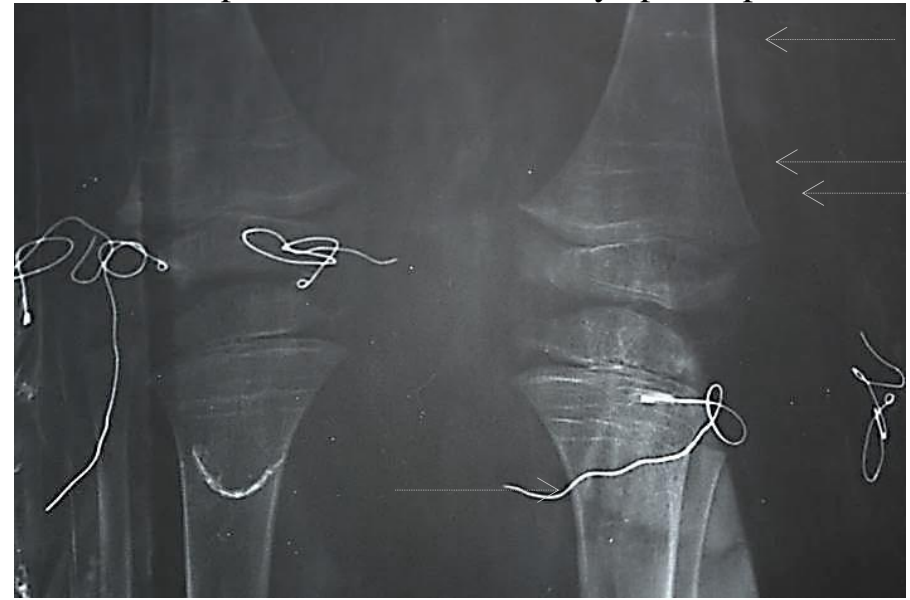

Fuente: Judith Ruiz y Jorge Gómez Valdés.

Figura 23. Líneas de Harris presentes en la momia 1. Se observan en epífisis distal de tibia y peroné, de ambos lados

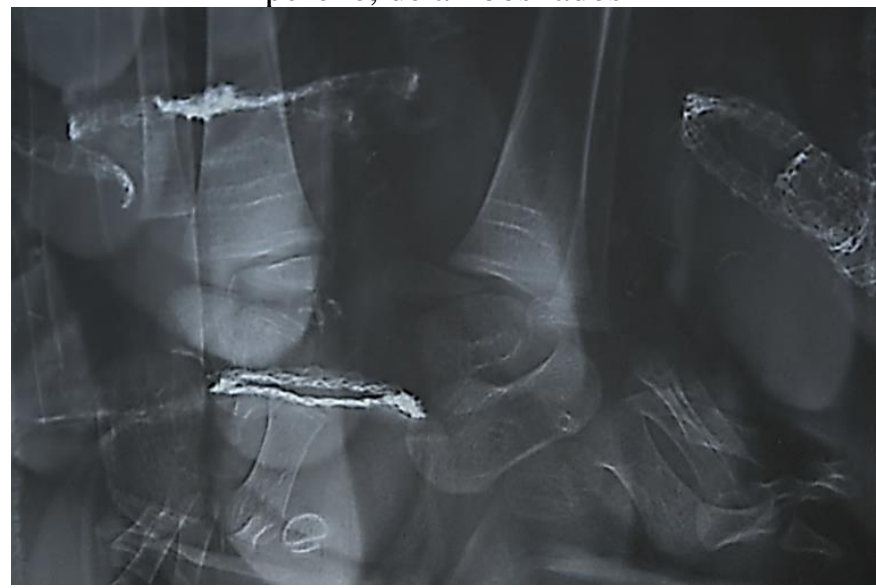

Fuente: Judith Ruiz y Jorge Gómez Valdés. 


\section{Traumatismos}

La evaluación de traumatismos observados en diferentes regiones del esqueleto da indicios de varios aspectos de la vida de grupos humanos del pasado. De este modo se pueden hacer inferencias sobre causas de muerte y patrones de comportamiento social, ya que es posible observar lesiones dejadas por la violencia interpersonal e intradoméstica, accidentes y, si existió, alguna intervención quirúrgica (Márquez-Morfín, 2006; Medrano-Enríquez, 2008; Ortner, 2003).

Se entiende por trauma una lesión ósea que resulta como desequilibrio entre la estabilidad del hueso y las fuerzas (más externas que internas) que lo afectan. Los huesos se fracturan según el sentido en que actúan las fuerzas, y esto ocurre cuando hay una flexión, torsión, cizallamiento, compresión y tracción (Campillo, 2001).

Además de la rotura ósea con pérdida de la continuidad cortical, hay otras alteraciones que se producen por un traumatismo: lesión del periostio, edema, presencia de hematomas por roturas vasculares, áreas de necrosis ósea o de tejidos vasculares, roturas musculares, presencia de cuerpos extraños en las fracturas abiertas e infecciones. Algunas fracturas pueden penetrar en cavidades orgánicas, como en el caso de las costillas, o poner en comunicación una cavidad con el exterior, como ocurre con las fracturas de la base del cráneo. Cualesquiera sean, las fracturas pueden ocurrir en vida o ser póstumas. Las primeras son evidentes cuando hay signos de reacción ósea cicatricial y, cuando las fracturas producen el fallecimiento del individuo o se dan en el trascurso de este, no hay signo de reacción vital (Campillo, 2001).

En cuatro de las nueve momias hay signos de traumatismos que, por sus características, llevan a suponer que en dos de ellas - momias 8 y 9 - probablemente fueron la causa de muerte, mientras que las otras pudieron haber ocurrido en el momento de la muerte (peri mortem) - momias 2 y 4-, pues en ninguno de los casos hay huella de recuperación ósea y se observa alteración en la superficie cortical. En seguida se describirá cada caso.

\section{Momia 2}

A través de la radiografía anteroposterior de extremidades superiores, se pudo identificar un traumatismo o fractura subcapital (que afecta a cualquier zona proximal del húmero) en el extremo superior del húmero izquierdo. Específicamente, se trata de una fractura en el área del troquíter (tuberosidad de la cabeza humeral que da inserción al músculo supraespinoso), con desplazamiento bajo el acromion.

Generalmente, esta fractura se produce por un golpe directo a la cabeza humeral, en una caída de lado contra el suelo, y suele presentar dolor de regular intensidad, limitación al movimiento de abducción o movilidad parcial. (figura 24) (Pedro-Moro, Pérez-Caballer, 1999). 
Figura 24. Momia 2. Fractura de troquíter en epífisis proximal de húmero izquierdo. (1) Se observa desplazamiento bajo acromion y (2) fragmento de troquíter impactado

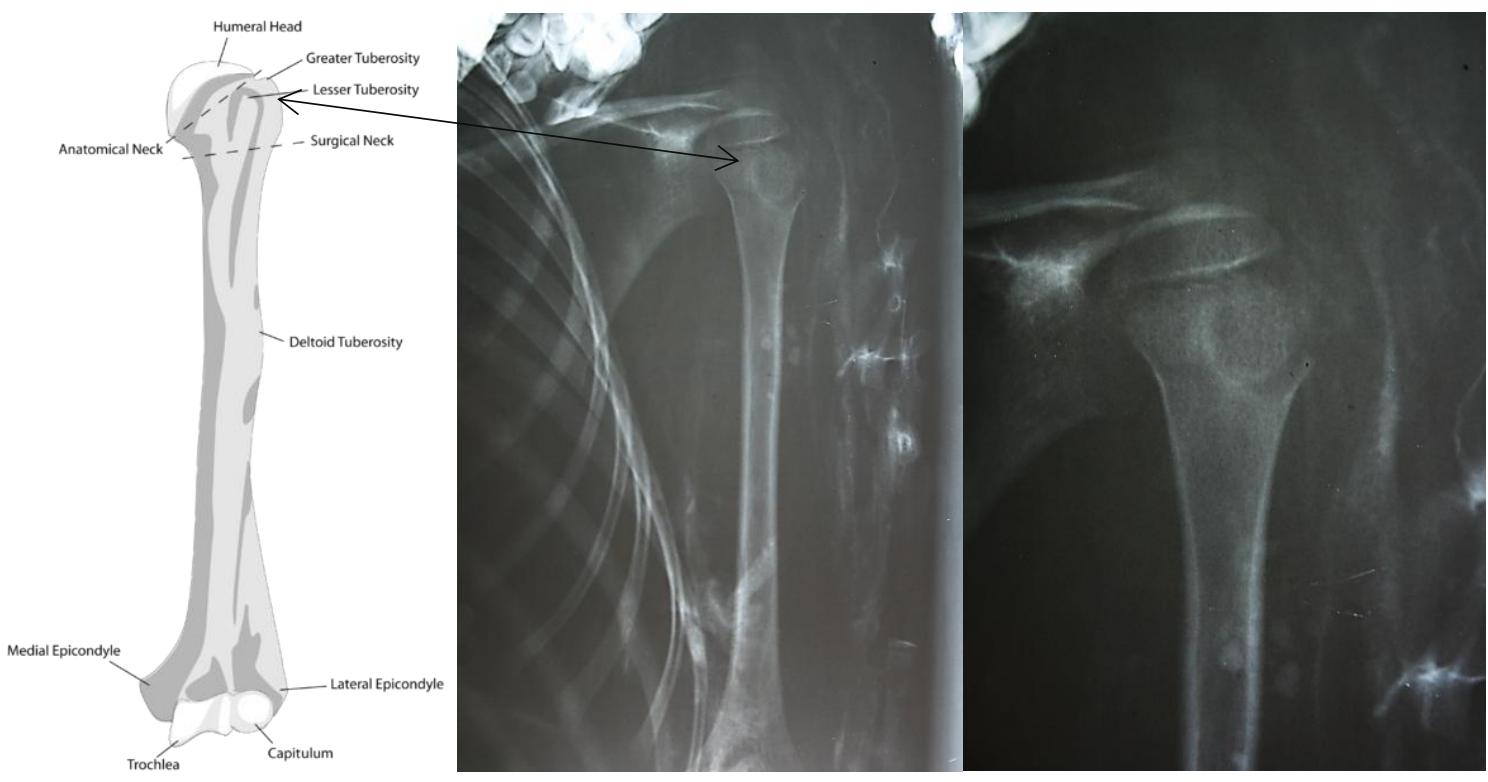

Fuente: Judith Ruiz y Jorge Gómez Valdés.

\section{Momia 4}

En la extremidad superior izquierda se aprecia un traumatismo con dislocación de codo y fractura de la cavidad olecraneana, afectando específicamente una porción de la metáfisis del cóndilo, pues se observa ruptura de la línea cortical, además de cuatro fragmentos de hueso en el área afectada que no corresponden con los centros secundarios que posteriormente se osifican (figura 25) (Pedro-Moro, Pérez-Caballer, 1999).

Figura 25. Fractura de codo en momia 4
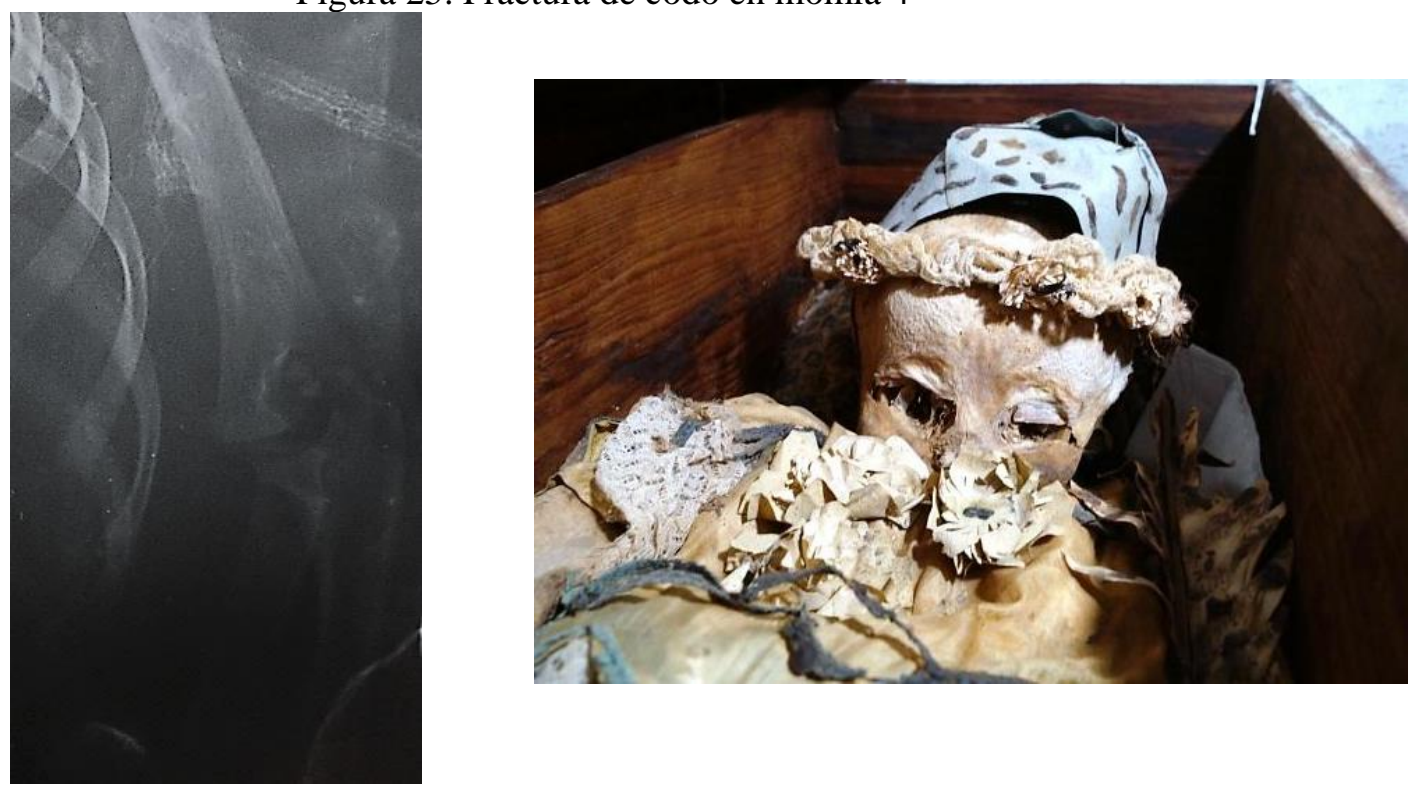

Fuente: Judith Ruiz y Jorge Gómez Valdés. 


\section{Momia 8}

En el área del occipital se evidencia la presencia de un traumatismo cráneal que fue causado por una caída. Como se trata de un individuo pequeño, las suturas craneales no se obliteraron, y menos aún las cuatro partes que conforman el occipital, las cuales se fusionan en un solo elemento a los seis años de edad; por ello es fácil confundir la lesión con las suturas abiertas. El tipo de fractura en esta momia es diastática, es decir, ocurre a lo largo de las líneas de sutura del cráneo y frecuentemente tiene mayor incidencia en recién nacidos y bebés grandes.

En la figura 26 se observa el traumatismo en vértice de la sutura lamboidea, con pérdida de la continuidad de cortical (1), así como una imagen bilobulada de bordes irregulares como consecuencia del impacto (2). A raíz del traumatismo, se ocasionó alargamiento del espacio intervertebral entre $\mathrm{C} 2$ y C3 con $10^{\circ}$ de angulación (3), que probablemente pudo provocar daño medular.

Si bien en un inicio se mencionó que algunos segmentos anatómicos en las momias se encuentran desarticulados, la separación entre las dos primeras vértebras cervicales y la $\mathrm{C} 3$ en esta momia es producto del traumatismo, pues es evidente, a pesar de la separación, un alineamiento normal de la columna vertebral (figuras 26 y 27).

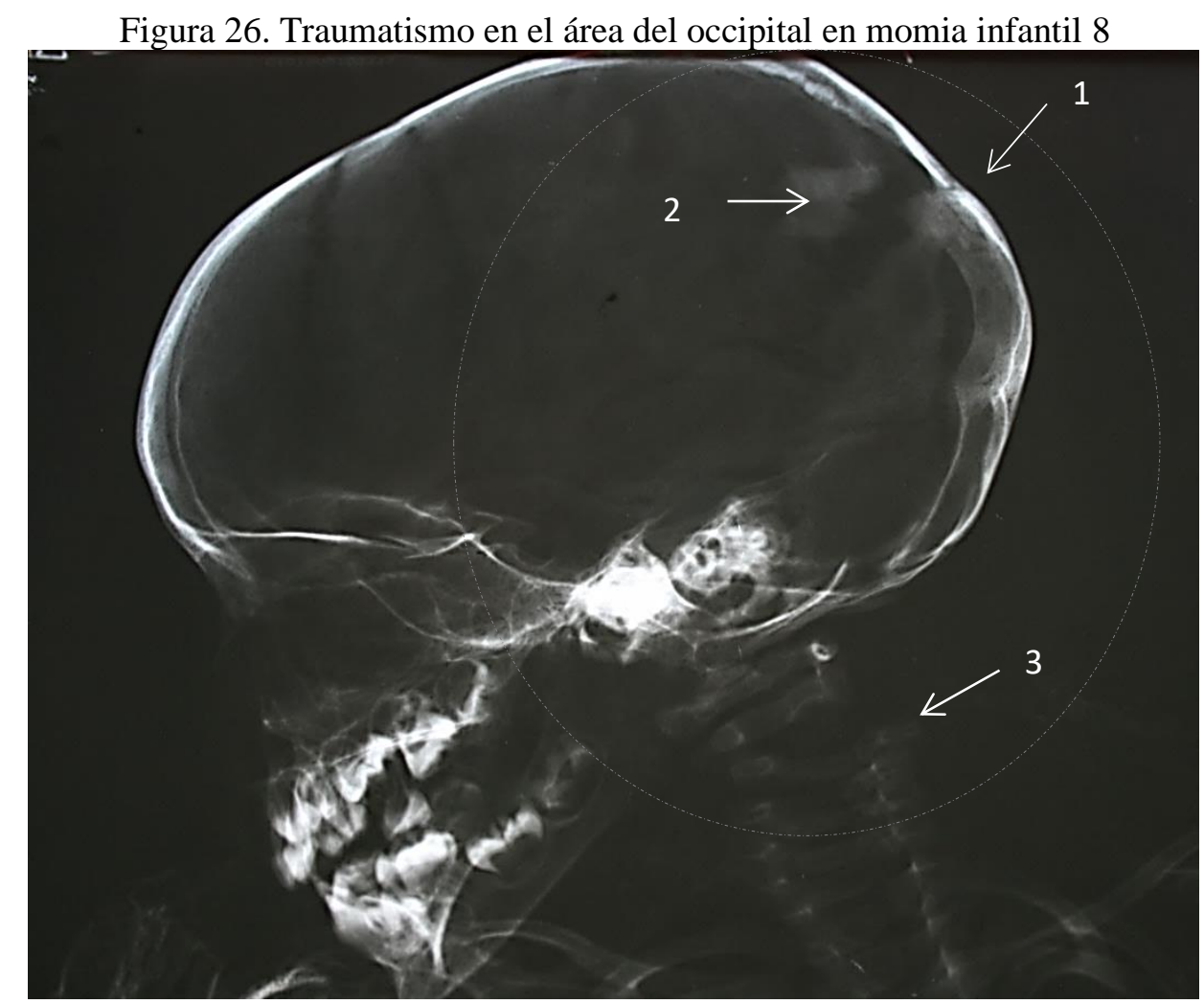

Fuente: Judith Ruiz y Jorge Gómez Valdés. 
Figura 27. Momia 8

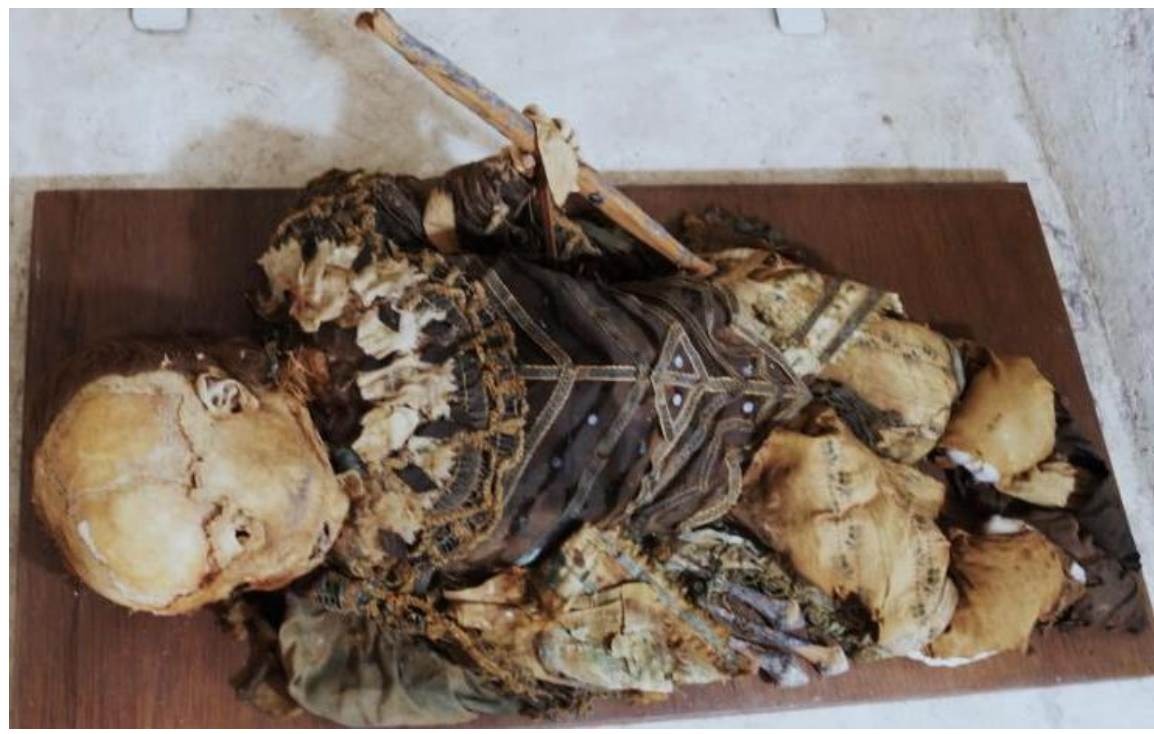

Fuente: Judith Ruiz

La literatura menciona que existe una alta incidencia de heridas en la cabeza en niños como resultado de caídas. Algunos de estos traumatismos pueden ser graves y hasta poner en peligro la vida. Se ha establecido, por ejemplo, que las caídas pediátricas son la tercera causa de mortalidad en niños de uno a cuatro años de edad, y la mayoría de los pacientes sufren una única lesión mayor que por lo general afecta la cabeza o el sistema musculoesquelético. Muchos niños pueden sobrevivir a caídas desde alturas significativas a pesar de sufrir lesiones graves, pero con la altura de la caída aumentan la morbilidad y la mortalidad (Wilber y Thompson, 2000, p. 71-74).

Asimismo, hay diferencias en las proporciones corporales entre niños y adultos que producen un espectro de lesiones distinto. Por ejemplo, la cabeza del niño es más grande en relación con el cuerpo, y cuanto menor es el niño, más extensa es la cabeza. Esta desproporción hace que la cabeza y el cuello sean más vulnerables a las lesiones, en especial a las caídas desde alguna altura, porque el peso de la cabeza hace que ésta choque primero con el piso, mientras que los adultos, por el contrario, tienen más propensión a protegerse con sus extremidades. Estas, en el caso de los niños, son más cortas y carecen de fuerza para proteger de manera adecuada durante una caída.

\section{Momia 9}

En la figura 28 se evidencia un traumatismo craneal en el área del occipital con fractura de la tabla interna, el cual provocó una fisura que se origina cerca del punto de impacto y llega hasta el hueso frontal, causada por compresión de un golpe, probablemente a raíz de un acto violento o como consecuencia de un accidente. En este caso, quizá la causa de muerte fue un golpe agudo que le propinaron en la cabeza al individuo, específicamente en la parte posterior. 
Figura 28. Imagen del cráneo de momia 9 y traumatismo en occipital
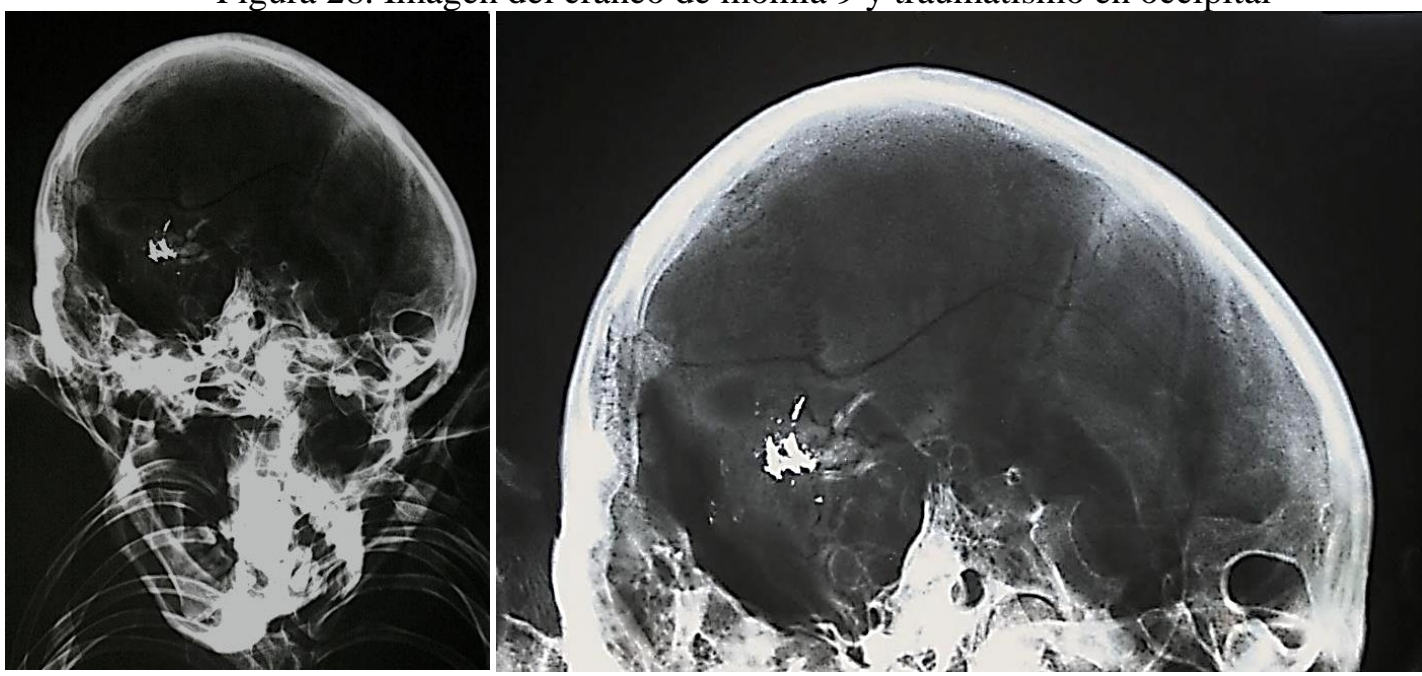

Fuente: Judith Ruiz y Jorge Gómez Valdés.

\section{Procesos degenerativos en momia 9}

Los padecimientos degenerativos articulares afectan el sistema musculo-esquelético que, como sostén y protector del cuerpo, proporciona movimiento al esqueleto. Consisten en el desgaste de las articulaciones expuestas a un mayor esfuerzo debido a la fricción entre ellas, que da lugar a un crecimiento óseo que se presenta desde una forma ligera hasta llegar a inmovilizar los elementos involucrados (Campillo, 2001).

La presencia de estos padecimientos es muy antigua, ya que se ha registrado desde el Paleolítico y Neolítico en individuos menores de 30 años (Iglesias-Gamarra, Quintana y Restrepo, 2006). Afectan a hombres y mujeres de cualquier edad y su etiología es múltiple, ya que está relacionada con el proceso de envejecimiento, el tipo de trabajo efectuado por las personas, malas posturas al realizar esfuerzos, exceso de peso corporal o cargar peso de manera cotidiana. Asimismo, cabe considerar como factores el medio ambiente, trastornos de la dieta, traumatismos, el sexo y la carga genética de los individuos (Medrano-Enríquez, 2008; Ortner, 2003).

La osteoartritis, artrosis o enfermedad degenerativa de las articulaciones es el tipo más común de artritis. Esta es una de las lesiones degenerativas más frecuentes e identificables en los restos esqueléticos y momificados, y se caracteriza por el desgaste del cartílago articular con crecimiento óseo en las orillas de las articulaciones involucradas. El cartílago es la parte final de los huesos que les permite fácil movimiento, y su desgaste hace que los huesos friccionen uno contra otro, causando rigidez, dolor y pérdida de movimiento articular. Típicamente, las articulaciones afectadas en estos casos son la cadera, las manos, las rodillas, la espalda baja y el cuello. Según la literatura, los síntomas inician a partir de los 40 años y avanzan lentamente; después de los 50 años de edad, afectan más a las mujeres.

Se desconoce la causa directa de este padecimiento, pero hay ciertos factores que aumentan el riesgo de desarrollarla: herencia, sobrepeso, lesiones de las articulaciones, uso excesivo o repetitivo de algunas articulaciones, falta de actividad física, daños en los nervios y envejecimiento (Campillo, 2001). La pérdida progresiva del espacio articular requiere atención ya que el grosor de cada espacio cartilaginoso debe guardar una 
proporción en relación con la movilidad del segmento: cuanto más grande sea la proporción, más móvil será el segmento.

La osteoartritis es visible en algunas articulaciones de la momia 9, con afectación ligera de la columna vertebral. También se ven comprometidos la articulación sacroilíaca, el acetábulo femoral, la rodilla y el tobillo (figuras 29 y 30). Cabe anotar que en los demás segmentos óseos no es posible evaluar la presencia de estas lesiones por la superposición de imágenes o porque no se radiografiaron todos los segmentos anatómicos de la momia.

En particular, son notables la disminución del espacio articular en el acetábulo femoral y, en la región sacroilíaca, la formación de rebordes óseos. Todos estos cambios son interpretados como resultado del paso de los años, relacionados al desgaste biomecánico del esqueleto.

Figura 29. Presencia de osteofitos en articulación sacroilíaca y disminución del espacio articular en el acetábulo femoral.

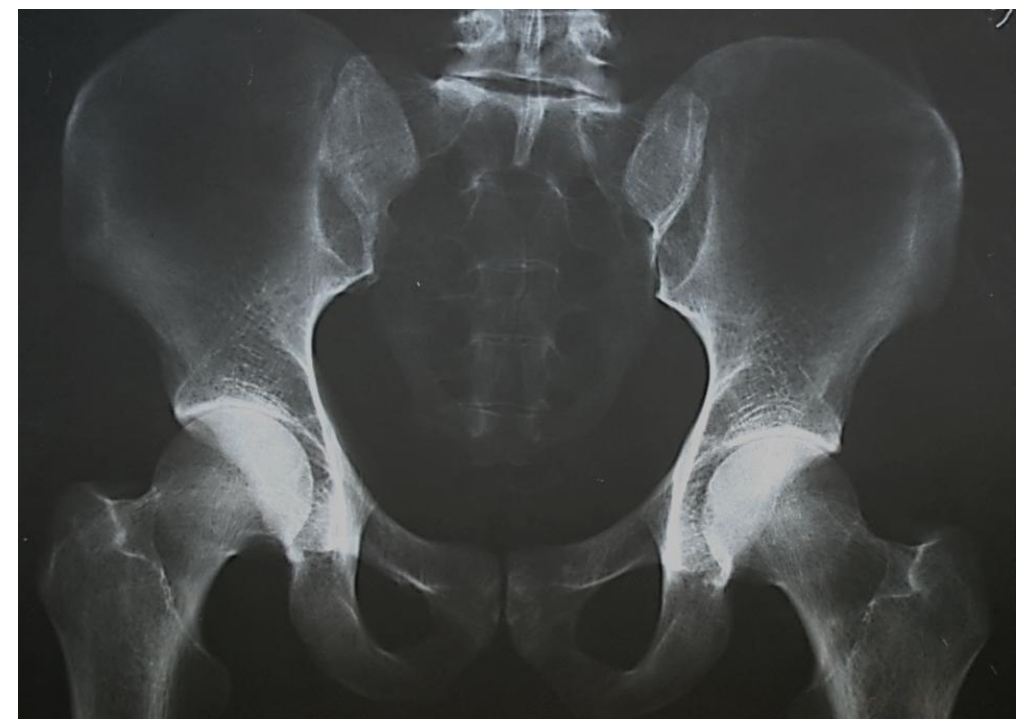

Fuente: Judith Ruiz y Jorge Gómez Valdés.

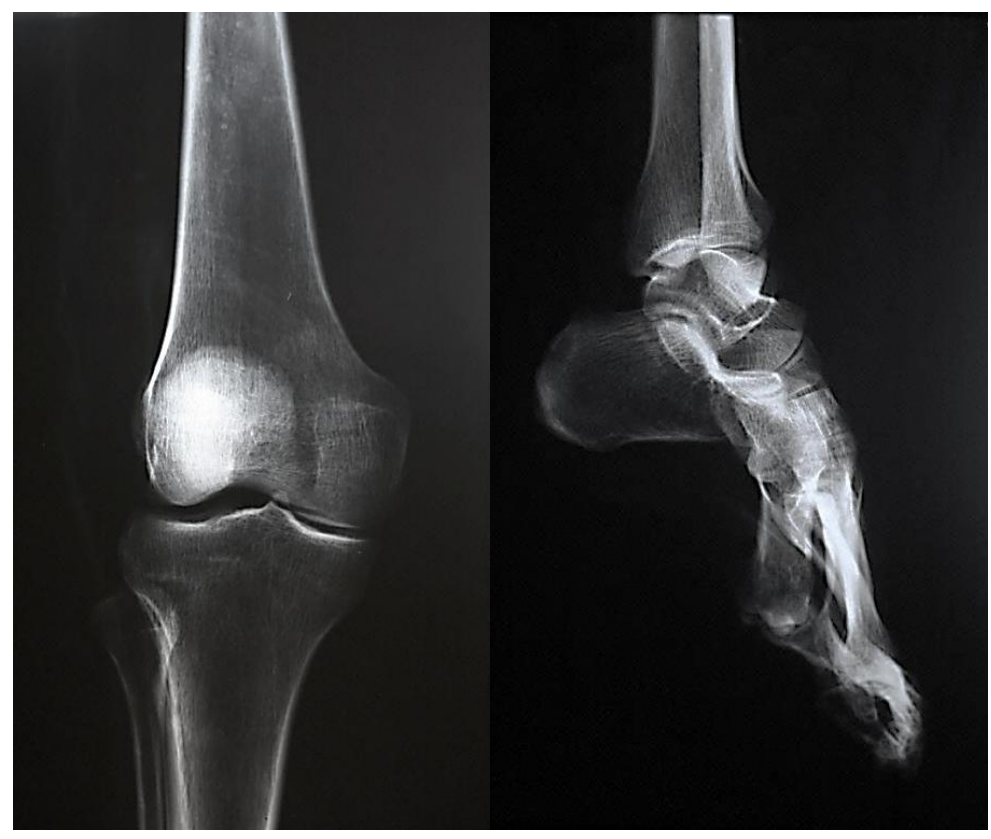

Figura 30. Izquierda: artrosis de rodilla izquierda o gonartrosis; se aprecia afectación del compartimento femorotibial interno, con disminución del espacio intertibial.

Derecha: disminución del espacio articular en tobillo derecho

Fuente: Judith Ruiz y Jorge Gómez Valdés. 


\section{Consideraciones finales}

Las momias de Tlayacapan retratan un fragmento del sistema de pensamiento novohispano y, asimismo, se enmarcan en un proceso de cambio de índole económico y social con el advenimiento del México independiente. Es precisamente a inicios del siglo XIX que se vive en la Nueva España una crisis agrícola que trastocó el ámbito social y económico, llegó a convertirse en crisis de subsistencia para las poblaciones y repercutió en materia de salud.

Las crisis agrícolas eran un fenómeno periódico en la Nueva España, por lo cual resultaban inevitables, debido a que la mayor parte de la agricultura seguía siendo de temporal y quedaba a merced de la sequía, las inundaciones, las heladas, el granizo y las plagas. En una sociedad agraria y profundamente desigual, la situación se agravaba porque no se tenía la infraestructura suficiente para transportar grandes y pesados volúmenes de alimentos hacia regiones distantes y golpeadas por la crisis, y además porque los grandes productores y comerciantes aprovechaban la escasez de alimentos para especular con los precios. Tales momentos aciagos se convertían en verdaderas crisis de subsistencia, pero en América, en general, estos fueron solo episodios breves que no llegaron a modificar esencialmente los regímenes alimenticios (Molina del Villar, 2010).

Durante el periodo de 1809-1811, en el centro del país se gestó una crisis de subsistencia, en la que la capital y otras localidades del centro de México padecieron de escasez de alimentos. Durante esta etapa muchos pueblos tuvieron que aportar alimento para el abasto púbico de la ciudad de México, que era la prioridad social en aquel entonces (Molina del Villar, 2010).

Estos hechos nos proveen un marco social para explicar las condiciones de salud de los nueve individuos momificados del presente estudio. El grupo de edad que se encuentra en mayor proporción en la muestra es el de la primera infancia y, en menor medida, de la segunda infancia (momias 6 y 7), además de un adulto maduro.

En general se observa que las condiciones de salud no fueron del todo favorables debido a la presencia de lesiones óseas como respuesta adaptativa del organismo ante situaciones adversas, por el desequilibrio fisiológico que vivieron en su infancia. Esta situación de estrés durante la niñez produjo un rezago importante en el crecimiento en individuos que, debido a su estatus de salud, no tuvieron la habilidad de sobrevivir a estas edades vulnerables.

A pesar de que en las momias no fue posible observar problemas de estrés específico como deficiencias nutricionales (hiperostosis porótica y criba orbitalia) o infección (periostitis), es muy probable que su muerte esté asociada a la exposición prolongada a enfermedades infecciosas o respiratorias que son muy comunes a estas edades, pues en sus huesos hay evidencia fisiológica, específicamente, de periodos de estrés episódico y acumulado, de la adaptación del organismo ante condiciones adversas, de las cuales no pudieron sobrevivir a edades más avanzadas. Es decir, el organismo de estos individuos fue sometido a periodos de estrés continuos. De lo contrario, si su muerte hubiera sido inmediatamente después de haber estado expuestos a alguna enfermedad, en sus huesos no se reconocerían lesiones, debido a que se necesita de un tiempo prolongado para que el tejido óseo se altere. 
El medio ambiente también es un factor determinante en el proceso de salud y enfermedad. En ese sentido, se ha encontrado que en los climas húmedos y calientes ocurre una acción sinérgica entre enfermedades por parásitos e infecciosas (Johnston, 1962, en Peña-Reyes et al., 2007). De manera que la explicación sobre la edad a la muerte en las momias y la influencia del estatus de salud en el potencial de crecimiento tendría su origen en las condiciones de vida insanas que prevalecían en un medio húmedo y cálido. Así las cosas, es probable que aun para la gente noble y acomodada del lugar fuera difícil contrarrestar la morbilidad a ciertas edades de la vida. Puede ser que el acceso a los recursos básicos para la sobrevivencia humana, como la alimentación, el abastecimiento de agua limpia y la higiene, fuera deficiente.

En el caso de la alimentación, si es que hubo recursos, se infiere que el aprovechamiento de ciertos nutrientes y/o sustancias fue deficiente, quizá por la presencia de parásitos intestinales que intervienen en ello, debido al consumo de alimentos contaminados que producen enfermedades intestinales. Entre los problemas que se desarrollan por deficiencia de nutrientes se encuentra la afectación del crecimiento longitudinal.

Todavía en el siglo XIX la distribución del agua se hacía mediante espacios públicos localizados en las plazas y lugares accesibles para la población (Cabrera Gallardo, 2005). En el caso de Tlayacapan, que solo cuenta con corrientes temporales, la escasez de agua propició la construcción de jagüeyes en el poblado, y a nivel doméstico se crearon los aljibes para recoger el agua de la lluvia, cuyos vestigios se pueden encontrar en lo que fuera la huerta del convento agustino y uno más en La Cerería, que ahora es Casa de Cultura (Meraz-Quintana y Soria-López, 2012). Probablemente, la gente se abastecía de estos lugares; sin embargo, como son depósitos artificiales de agua, esto propiciaba que el líquido no fuera de la mejor calidad. Así, al tratarse de agua antihigiénica para la preparación de alimentos y el uso cotidiano, las enfermedades parasitarias encontraron hospederos para manifestarse en el estado nutricional de los habitantes de Tlayacapan.

Es de recordar que durante la época colonial los niños representaban el $40 \%$ de la población, y pese a ello existía una gran mortalidad infantil que llegaba tanto a familias adineradas como a las pobres, urbanas y campesinas y de todas las etnias. Los niños recién nacidos hasta su primera infancia fueron así el sector más vulnerable. Uno de cada cuatro bebés no llegaba a cumplir un año de vida, otra cuarta parte fallecía antes de cumplir los 10 años, y solo el $50 \%$ sobrevivía para entrar a la adolescencia. En el caso de las familias nobles, uno de cada cuatro hijos moría antes de los cinco años de vida (Masferrer, 2010; López Ramos, 2000).

En el siglo XIX aún se hace referencia constante a la muerte infantil en los periódicos de la Ciudad de México, durante una época en que aún no se propagaba el conocimiento de la asepsia, la anestesia, la inoculación y la vacunación. De este modo, la alta mortalidad infantil se debía a las enfermedades mortales que incidían en los primeros meses de existencia. Las más comunes fueron las gastrointestinales o diarreicas y las infecciones pulmonares o respiratorias agudas, sin dejar a un lado las epidemias. Otros de los factores importantes que intervenían en este fenómeno fueron la lactancia, el destete y el tipo de dieta, así como la insuficiencia en las políticas de higiene y salud (Tanck de Estrada, 2005; López-Ramos, 2000) ${ }^{9}$.

\footnotetext{
${ }^{9}$ Todavía en el siglo XVIII se presentaron varios brotes epidémicos que diezmaban a la población, a pesar de que ya se había hecho la campaña masiva de vacunación contra la viruela en todas las posesiones de la Corona Española en 1803 (Márquez, 1994).
} 
También es importante señalar el papel de la crianza en la sobrevivencia a edades tempranas, pues de ello depende que a los niños se les proporcione una dieta adecuada y los cuidados necesarios en esta etapa de la vida. Asimismo, otra de las causas de la mortalidad infantil durante la época colonial fueron las caídas y los golpes, asociados también a la crianza de los niños. Este hecho se puede atestiguar en los traumatismos y las fracturas visibles en los huesos de algunas momias, ocurridos un poco antes o en el momento de la muerte.

Todo lo anterior es muestra evidente de cómo las condiciones y los estilos de vida son cambiantes a lo largo del proceso histórico, de manera que no resultan comparables por épocas, en este caso, entre la época colonial y la actual. Sin embargo, es claro que, en todo caso, estos elementos del contexto inciden en el estado de salud de las personas.

Del mismo modo, tampoco son equiparables las condiciones de vida de la clase alta de la época colonial con las de las clases media y alta actuales por las posibilidades en la alimentación, la sanidad, el acceso a antibióticos, etc., menos aún si se trata de un poblado que en la época colonial no se encontraba cerca de la ciudad y por cuya lejanía no contaba con las mismas oportunidades de acceso a la sanidad y a los recursos alimentarios. Así, si bien Tlayacapan es una región de tierra fértil, la gente de la época mencionada se encontraba a expensas de la agricultura de temporal y no contaba con los productos de la ciudad.

\section{Agradecimientos}

Al Dr. Jorge A. Gómez-Valdés por su colaboración en el registro radiográfico.

A la Dra. Abigail Meza Peñaloza por habernos proporcionado el equipo para el trabajo de campo.

Al Programa de becas Conacyt por el apoyo recibido para desarrollar esta investigación durante la Maestría en Estudios Mesoamericanos.

Al Museo de Sitio de Tlayacapan, Morelos, por las facilidades otorgadas para el acceso a los materiales de estudio.

\section{Referencias}

Aufderheide, A. (2003), The scientific study of mummies, Cambridge, Cambridge University Press.

Ávila-Sánchez, H. (2002). Aspectos históricos de la formación de regiones en el estado de Morelos (desde sus orígenes hasta 1930). Cuernavaca, Morelos: UNAM, Centro Regional de Investigaciones Multidisciplinarias.

Batres, L. (1889). Momia tolteca. Antropología Mexicana (pp. 1-6). México: Tipografía de la Escuela Nacional de Artes y Oficios/Exc Convento de San Lázaro.

Bautista-Martínez, J., Gómez-Valdez, J. y Ortega-Palma, A. (2010). Microbiología de las momias del Museo de las Ánimas. En Perspectiva tafonómica II. Nuevos trabajos en torno a poblaciones mexicanas desaparecidas (pp.57-64). Colección CientíficaINAH. Coord. Pijoan Aguadé Carmen M., Lizarraga Cruchaga, Javier, Valenzuela Jímenez, Gerardo.

Bautista-Martínez, J. y Gómez-Valdez Jorge A. (2012). El proceso de toma radiográfica de bienes culturales. En Manual de radiología aplicada al estudio de bienes culturales. Colegio de Michoacán y Escuela de Conservación y Restauración de Occidente. Josefina Bautista Martínez y Mirta Insaurralde Caballero (Coords.). (pp. 43-58). 
Bautista-Martínez, J., Gómez-Valdez, J. A. y Monterroso-Rivas, P. N. (2012). Radiología aplicada al estudio de huesos. En Manual de radiología aplicada al estudio de bienes culturales (pp. 59-80). Colegio de Michoacán y Escuela de Conservación y Restauración de Occidente. Josefina Bautista Martínez y Mirta Insaurralde Caballero (Coords.)

Buikstra, J. E. y Ubelaker, D. H. (1994). Standards for Data Collection from Human Skeletal Remains. Arkansas. Archaeological Survey Research Series No 44, Arkansas.

Castillo-Chávez, O. (2000). Condiciones de vida y salud de una muestra poblacional de la Ciudad de México en la época colonial. Tesis de maestría en antropología física, ENAH, México.

Campillo, D. (2001). Introducción a la paleopatología, Bellaterra, Barcelona.

Cockburn, A., Cockburn, E. y Reyman, T. A. (1998). Mummies, disease \& ancient cultures. Oxford: Cambridge University Press.

Cabrera Gallardo, R. (2005). Condiciones de salud en una muestra ósea procedente del panteón de Santa Paula, D. F. de finales del s. XVIII y principios del s. XIX (Tesis de licenciatura), ENAN, México D. F.

Demirjian A., Goldstein H. y Tanner J.M. (1973). A new system for dental age assessment, Human Biology, Vol. 45, Núm. 2: 211-227.

De Pedro- Moro, J. A. y Pérez-Caballer, A. J. (1999). Ortopedia y Traumatología. Editorial médica Panamericana.

Faulhaber-Kamman, J. (1976). Investigación longitudinal del crecimiento en un grupo de niños caracterizados por su ambiente socioeconómico, su alimentación y su patología. Colección Científica 6. México D. F.: INAH, SEP.

Frenk, J., Bobadilla, J. L., Stern, C., Frejka, T. y Lozano, R. (1991). Elementos para una teoría de la transición en salud. Revista de Salud Pública en México, 33(5), 448462.

Goodman, A. H. y Martin, D. L. (2002). Reconstructing health profiles from skeletal remains. En R. H. Steckel y J. C. Rose (Eds.), The back bone of history health and nutrition in the Western Hemisphere (pp. 11-60). Cambridge University Press.

Hernández-Espinosa, O. P. y Peña-Reyes, M. E. (2010). Manual para la identificación del sexo y la estimación de la edad a la muerte en esqueletos menores de quince años. México: INAH-ENAH.

Hesinger, R. N. (2000). Complicaciones de las fracturas en niños. En Traumatismo esquelético en niños (pp. 121-148). 2. ${ }^{\mathrm{a}}$ ed. México: Médica Panamericana. Green, Neil E., autor.

Iglesias-Gamarra A., Quintana G. y. Restrepo-Suárez, J. F. (2006). Prehistoria historia del arte de la Reumatología. Inicios de las palabras reuma, artritis reumatoide, artritis juvenil, gota y espondilitis anquilosante, Revista Colombiana de Reumatología, Vol. 3, Núm. 1, Bogotá, marzo.

Insaurralde-Caballero, M. (2012). Importancia del diagnóstico por imágenes en el ámbito de la conservación y restauración de bienes culturales. En Manual de radiología aplicada al estudio de bienes culturales (pp. 25-42). Colegio de Michoacán y Escuela de Conservación y Restauración de Occidente. Josefina Bautista Martínez y Mirta Insaurralde Caballero (Coords.)

Krenzer, U. (2006). Determinación de la edad osteológica en subadultos, Compendio de Métodos Antropológicos Forenses para la reconstrucción del perfil osteobiológico, tomo IV, CAFCA, Guatemala.

Lazala, O. (2009). Líneas de Harris. Revista Colombiana de Ortopedia y Traumatología, 23(2), 127-128. 
Leboreiro-Reyna, I. S. (2004). Estudio físico-químico del fenómeno de fluorescencia ósea: una propuesta de evaluación e interpretación en material humano arqueológico (Tesis de licenciatura en Antropología Física). ENAH, México.

Leboreiro-Reyna, I. S. (2005). Procedencia F10: una momia traspapelada. Cuicuilco, 12(35), 165-180. México: ENAH.

Lerma-Gómez, M. C. (2008). Las momias en México. Propuesta metodológica para su manejo, un estudio de caso (Tesis de licenciatura en Antropología Física). ENAH, México D. F.

López-Alonso, S. (1971). La escotadura ciática mayor en la determinación sexual de restos óseos prehispánicos de México. Anales del INAH (2), 31-41.

López-González, V. (1994). Historia general del estado de Morelos. Antecedentes y formación del estado de Morelos. Tomo 1. Morelos: Centro de Estudios Históricos y Sociales.

López-Martínez, R., Hernández-Hernández, F., Millán, B. E., Manzano, P. y Méndez Tovar, L. J. (2007). Efectividad del imazalil en el control del deterioro por hongos de momias del museo de El Carmen, Ciudad de México. Revista Iberoamericana de Micología, 24, 283-288.

López-Ramos, S. (2000). Prensa, cuerpo y salud en el siglo XIX mexicano (1840-1900). México: Ceapac.

Luna, L. (2006). Alcances y limitaciones del concepto de estrés en arqueología. Antípoda (3), 255-279. Buenos Aires.

Malvido, E. (1999). Ritos funerarios en el México colonial. Revista de Arqueología Mexicana, VII (40), 46-51.

Malvido, E. (2003). La guerra contra las momias de la Nueva España en el siglo XVIII: jesuitas, franciscanos, autoridades seculares e inquisición, Antropología Física, Disciplina plural. INAH, México, pp. 261-274. Mansilla, J. y Xavier Lizarraga (ed.).

Mansilla-Lory, J. (2002). Proyecto de investigación: Las momias de México. Diario de Campo. Por los caminos de la antropología física (16), 30-31.

Márquez-Morfín, L. y González-Crespo, N. (1985). Las momias de la Iglesia de Santa Elena, Yucatán: Estudio antropofísico. Colección Científica. México: INAH, SEP/Cultura. Maresh, M.M. (1963) Tissue changes in the individual during growth from $x$-rays of the extremities. Ann NY Acad Sci 110:465-474

Márquez-Morfín, L. (1984). Sociedad Colonial y enfermedad. Un ensayo de osteopatología diferencial. INAH. México. D.F

Márquez-Morfín, L. (1994). La desigualdad ante la muerte en la Ciudad de México. El tifo y el cólera. Siglo XXI. México. D.F.

Márquez-Morfín, L. y Hernández-Espinosa, P. (2006). Nuevas tendencias de estudio en la ENAH sobre salud y nutrición en poblaciones antiguas, Salud y sociedad en el México prehispánico y colonial. CONACULTA-INAH, México, pp.15-26. Lourdes Márquez Morfin, (coord.)

Masferrer León, C. V. (2010). Hijos, huérfanos y expósitos. Un recorrido por la niñez de la época colonial novohispana. En Los niños, actores sociales ignorados. Levantando el velo, una mirada al pasado (pp. 305-324). México: INAH. Coord. Lourdes Márquez Morfin.

Medina-Monzón, J. L. (1993). Las momias naturales. Vols. I, II y III. Vigo Cardeñoso, España.

Medrano-Enríquez, A. M. (2008). Condiciones de salud en una población minera del siglo XIX: Panuco Zacatecas. En Tendencias actuales de la Bioarqueología en México (pp. 107-130). Conaculta-INAH. Coord. Lourdes Márquez Morfin. 
Mejía-Pérez, E., Chávez-Balderas, X. y Chávez-Sánchez, R. (2009). Pepita la momia de la Sierra Gorda de Querétaro. Revista de Arqueología Mexicana, XVII

(99), 70-75.

Menéndez-Taboada, M. T. (2006). Composición química del cabello de momias prehispánicas: Una aproximación a la dieta y el entorno (Tesis de licenciatura). ENAH, México.

Meraz-Quintana, L. y Soria-López, F. J. (2012). Urbanismo y casa tradicional de Tlayacapan, Morelos. México. Reflexiones sobre su historia y futuro. En F. J. Sandoval y J. L. Sáinz (Coords.), Construcción con tierra. Pasado, presente y futuro (pp. 143-154). Valladolid: Cátedra Juan de Villanueva. Universidad de Valladolid. Recuperado de http://www5.uva.es/grupotierra/publicaciones/digital/libro2013/13tr-meraz.pdf.

Molina del Villar, A. (2010). Santa María de Guadalupe, Atlacomulco ante los aciagos años de principios del siglo XIX: conflictos locales, crisis agrícolas y epidemia, 1809-1814. CIESAS-DF. Relaciones 121, XXX, 109-136.

Neurath, J. (2008). Momias, piedras, chamanes y ancestros. Un estudio etnohistórico sobre la temporalidad de la muerte en el Gran Nayar. En C. Rodríguez, M. E. Sánchez y L. Báez (Coords.), Morir para vivir en Mesoamérica (pp. 23-56). México: Consejo Veracruzano de Arte Popular/INAH.

Oliveros, A. (1990). Las momias de Tlayacapan. Colección Divulgación. México: INAH.

Ortner, D. (2003). Differential diagnosis of skeletal lesions in infectious disease. En Advances in human paleopathology (pp. 191-214). Inglaterra.

Ortner, D. (2003). Differential diagnosis of skeletal lesions in infectious disease, Advances in human paleopathology, England, pp. 191-214.

Peña-Reyes, M. E., Hernández-Espinosa, P. O. y Márquez-Morfín, L. (2007). Estatus de crecimiento y condiciones de salud en los niños de Jaina. En La población prehispánica de Jaina. Estudio osteobiográfico de 106 esqueletos (pp. 139-178). México: ENAH-INAH. Patricia O. Hernández y Lourdes Márquez (Coords.)

Peña-Reyes, M. E. y González-Álvarez, C. (2010). Manual para la estimación de la edad en vértebras cervicales como indicador de madurez biológica. Materiales de Apoyo a la docencia/Bitácora. INAH.

Pijoan-Aguade, C. M. y Lizárraga-Cruchaga, X. (2004). Tafonomía: una mirada minuciosa a los restos mortuorios. En C. M. Pijoan-Aguade y X. LizárragaCruchaga (Eds.), Perspectiva tafonómica. Evidencias de alteraciones en restos óseos del México prehispánico (pp. 13-34). Colección Científica, Serie Antropología Física. México: INAH.

Rae-Simms, S. (2012). El caso de una momia prehispánica de Tamaulipas y la relevancia de los vegetales que la acompañan (Tesis de licenciatura en Antropología Física). ENAH, México.

Ramírez, F., Lazala, O., Rondón, F., Restrepo, J. F. e Iglesias, A. (2009). Evidencia radiográfica de la acción de los bifosfonatos en el esqueleto inmaduro. Revista Colombiana de Reumatología, 16(2), pp. 146-153.

Resnick Donald (2001). Huesos y articulaciones en imagen. Vols. 1 y 2. Madrid, España: Marbán.

Roche, A. F., Wainer H. y Thissen D. (1975). Skeletal Maturity. The knee joint as a biological indicator, Plenum, London.

Rodríguez-Álvarez, M. Á. (2001). Costumbres funerarias en la Nueva España. Usos y costumbres funerarias en la Nueva España. México: Colegio de Michoacán y Colegio Mexiquense. 
Rojo-Pérez, F. (1998). Riesgos ocupacionales por manejo de restos momificados (Tesis de licenciatura de Antropología Física). ENAH, México.

Rubial-García, A. (1989). El Convento agustino y la Sociedad Novohispana. UNAM, México.

Ruiz-González, J. L. (2011). Tlatelolco en la colonia: Condiciones de vida y salud de un sector de la población novohispana (Tesis de Antropología Física). ENAH, México.

Ruiz-González, J. L., Bazán-Mora, E., Barrera-Moreno, E. y López-Martínez, R. (2016). Estudio micológico para la conservación de las momias de Tlayacapan, Morelos. Revista de Estudios de Antropología Biológica, 18(2), 55-67. México: UNAM.

Sánchez-Crispín, M. (2009). Identificación de bacterias y hongos asociados a las momias de Caltimacán, Tasquillo, Hidalgo (Tesis de licenciatura de Antropología Física). ENAH, México D. F.

Sánchez del Olmo, S. (2009). "Dales señor, el descanso eterno..." Muerte y entierro de las elites indias de Michoacán en la época colonial. En Muerte y vida en el más allá. Siglos XVI-XVIII (pp. 77-92). Serie Historia Novohispana/81. México: UNAM. Gisela von Wobeser y Enriqueta Vila Vilar (edición)

Schaefer M., Black S. y Sheuer L. (2009). Juvenile osteology: A laboratory and field manual, Elsevier Inc. Academy Press.

Soto-Cortés, A. (2010). Reina y soberana. Una historia sobre la muerte en el México del siglo XVIII. Colección Posgrado. México: UNAM.

Tanck de Estrada, D. (2005). Muerte precoz. Los niños en el siglo XVIII. En Historia de la vida cotidiana en México. El siglo XVIII: entre tradición y cambio (pp. 213-245). Tomo III. México: Colegio de México y FCE. Coord. Pilar Gonzalbo Aizpuru

Terry-Canale, S. (2000). Lesiones fisiarias. En Traumatismo esquelético en niños (pp. 1758). 2. ${ }^{a}$ ed. México: Médica Panamericana. Green, Neil E., autor.

Tiesler-Blos, V. (2001). La estatura entre los mayas prehispánicos. Consideraciones bioculturales. Estudios de Antropología Biológica, Coloquio Juan Comas, Volumen $X$, pp.257-274, IIAUNAM, México. Enrique Serrano Carreto y María Villanueva Sagrado (edit.).

Ubelaker D. (1989). The estimation of age at death from immature human bone, Age Markers in the human skeleton. C. C. Thomas Pub., Springfield, Illinois, 55-70.

Vila-Gay, S. (1997). Diagnóstico por la imagen en paleopatología. Recomendaciones para su obtención e interpretación. En La enfermedad en los restos humanos arqueológicos. Actualización Conceptual y Metodológica (pp. 77-85). Actas del IV Congreso Nacional de paleopatología. Fundación Municipal de Cultura, Ayuntamiento de San Fernando, Universidad de Cádiz. Editores: Ayuntamiento de San Fernando, Fundación Municipal de Cultura: Universidad de Cádiz, Servicio de Publicaciones

Walker, R.A. y Lovejoy, C.O. (1985), Radiographic changes in the clavicle and proximal femur and their use in the determination of skeletal age at death. Am. J. Phys. Anthropol., 68: 67-78. doi:10.1002/ajpa.1330680107

Wilber, J. H. y Thompson, G. H. (2000). El niño con lesiones múltiples. En Traumatismo esquelético en niños (pp. 71-102). 2. ${ }^{a}$ ed. México: Médica Panamericana. Green, Neil E., autor. 